\title{
MEMBANGUN PENDIDIKAN KELUARGA DI ATAS PUNDI-PUNDI RABBANIYYAH
}

OTONG SURASMAN

Institut PTIQ Jakarta

otongmomonsurasman@gmail.com

\begin{abstract}
ABSTRAK
Melihat kondisi bangsa Indonesia saat ini, bahkan di seluruh belahan dunia yang sedang dilanda virus corona, mengalami kehidupan yang sangat memprihatinkan, termasuk musibah besar karena sudah menelan begitu sangat banyak akibat virus corona. Pada sisi lainnya, tentunya sangat penting untuk membangun pendidikan keluarga di atas pundi-pundi Rabbaniyyah ini, agar dalam menyikapi kehidupan, apa pun yang terjadi di sekitarnya atau di lingkungan manusia berada, tetap mempunyai keyakinan bahwa dibalik itu pasti ada hikmah yang bisa ambil sebagai pelajaran. Sehingga bagi manusia yang beriman, musibah virus corona adalah bisa dimaknai sebagai teguran dari Allah Swt bagi orang-orang yang mengingkari kebesaran dan kekuasan Allah Swt. Juga sekaligus mengingatkan kepada manusia yang tidak menggunakan akal sehatnya, agar mampu berpikir kembali, bahwa pemberian atau anugerah yang diberikan Allah Swt berupa kemampuan berpikir untuk berkarya, harus berupaya dengan kemampuan ilmunya untuk menciptakan kemaslahatan umum, bukan sebaliknya. Apalah artinya adanya PBB (Perserikatan Bangsa-Bangsa), ketika tidak mampu menciptakan keamanan dunia dan perdamaian dunia. Maka saatnyalah untuk kembali berpikir positif, bahwa manusia diciptakan Allah SWT dan dijadikan khalifah di muka bumi ini adalah bertugas memakmurkan bumi, bukan untuk menghancurkannya.
\end{abstract}

Kata Kunci: Pembangunan, Pendidikan Keluarga, Kantung Rabbaniyyah

\begin{abstract}
Seeing the condition of the Indonesian nation at this time, even in all parts of the world that are being hit by the corona virus, experiencing a very alarming life, including a major disaster because it has swallowed so much due to the corona virus. On the other hand, of course it is very important to build family education on these Rabbaniyyah coffers, so that in addressing life, whatever happens around it or in the human environment, it still has the belief that behind that there must be wisdom that can take lessons. So for people who believe, the corona virus disaster can be interpreted as a reprimand from Allah SWT for those who deny the greatness and power of Allah SWT. Also at the same time reminding humans who do not use their common sense, to be able to think again, that the gift or gift given by Allah SWT in the form of the ability to think to work, must strive with the ability of science to create general prosperity, it's not otherwise. What does it mean to have the United Nations (United Nations), when it is unable to create world security and world peace. So it's time to return to positive thinking, that man was created by Allah SWT and made a caliph on this earth is tasked with prospering the earth, not to destroy it.
\end{abstract}

Keywords: Building, Family Education, Above the Pockets of Rabbaniyyah 


\section{A. PENDAHULUAN}

Begitu sangat penting untuk membangun pendidikan keluarga di atas pundi-pundi Rabbaniyyah, di mana langkah awal untuk mencapai pendidikan tersebut, harus memahami terlebih dahulu faktor-faktor yang membentuk kepribadian (karakter) manusia, sehingga dapat dipahami dengan baik dan benar permasalahan yang dihadapi masyarakat saat ini, khususnya bangsa Indonesia tercinta ini. Memang diakui, bahwa pendidikan di Indonesia sangat pesat, mulai dari tingkat pendidikan anak-anak sampai tingkat mahasiswa, bahkan sampai pendidikan tingkat Strata 3. Akan tetapi, tidak ada jaminan setelah meyelesaikan pendidikan tersebut dapat mencapai tingkat pemikiran dan kepribadian yang prima, bilamana tidak ditanamkan sejak dini pendidikan Rabbaniyyah pada keluarga masing-masing, khususnya di dalam pembinaan keluarga sebagai madrasah pertaamanya.

Oleh sebab itu, betapa pentingnya menggali kembali potensi kitab suci Al-Qur'an, untuk mencari sumber dasar pendidikan Rabbaniyyah untuk menjadi dasar utama bangunan keluarga, agar mencapai keluarga yang mempunyai kepribadian (karakter) kuat, kokoh, berbudi pekerti luhur, tanggungjawab, berani menyampaikan nilai-nilai kebenaran, sehingga cita-cita luhur bangsa Indonesia dapat terwujud, yaitu mewujudkan masyarakat yang adil dan makmur serta tenteram dan sejahtera.

Untuk mewujudkan impian tersebut, tentunya memerlukan rujukan yang sangat akurat, dalam hal ini adalah firman Allah swt (Al-Qur'ân) dan hadits Nabi Muhammad saw, juga beberapa pendapat lainnya. Di mana sebuah harapan dengan diketemukannya faktor-faktor yang membangun kepribadian (karakter) di atas pundi-pundi Rabbaniyyah, dapat dijadikan solusi untuk memperbaiki bangsa Indonesia tercinta ini, yang saat ini mengalami berbagai macam krisis, terutama krisis kepemimpinan yang diakibatkan karena krisis akidah dan akhlak.

\section{B. METODE}

Penelitian pada penulisan jurnal ini termasuk ke dalam jenis penelitian yang menggunakan pendekatan kualitatif, bukan kuantitatif. Pendekatan kualitatif digunakan bila data yang hendak dikumpulkan adalah data kualitatif, yaitu data yang disajikan dalam bentuk kata atau kalimat. Penelitian kualitatif sangat mengutamakan kualitas data, sehingga dalam penelitian kualitatif tidak digunakan analisis statistika. ${ }^{1}$

Bilamana dilihat dari cara pembahasannya, maka penelitian ini termasuk ke dalam jenis penelitian deskriptif, bukan inferensial. Penelitian deskriptif hanya melukiskan, memaparkan, menuliskan, dan melaporkan suatu keadaan, suatu obyek atau suatu peristiwa fakta apa adanya, dan berupa penyingkapan fakta. Tujuan dari penelitian deskriptif ini adalah untuk membuat deskriptif, gambaran atau lukisan

1 Sulistyo-Basuki, Metode Penelitian (Jakarta: Penaku, 2010), 20. 
yang sistematis, faktual dan akurat mengenai fakta-fakta, sifat-sifat serta hubungan antar fenomena yang diselidiki. ${ }^{2}$ Sedangkan bilamana ditinjau dari tempat pelaksanaan penelitian, maka penelitian ini termasuk ke dalam jenis penelitian kepustakaan (library research), bukan penelitian laboratorium maupun penelitian lapangan. Penelitian kepustakaan bertujuan untuk mengumpulkan data dan informasi dengan bantuan jenis-jenis materi yang terdapat dalam kepustakaan. Sebagai contoh kitab-kitab tafsir, kitab-kitab hadis, koran, majalah, naskah-naskah, catatan, kisah sejarah, dokumen, dan lain-lain. Yang mana pada hakikatnya, data-data yang didapat dengan jalan penelitian kepustakaan dijadikan dasar dan alat utama bagi analisis praktik penelitian.

Kemudian untuk mempermudah penjelasan mengenai metodologi penelitian yang digunakan, maka perlu adanya uraian langkah-langkah sistematis yang ditempuh dalam penelitian ini. Langkah-langkah tersebut adalah sebagai berikut:

\section{Metode Penelitian}

Mengapa dalam penulisan jurnal ini, penulis memakai metode maudhu'i? Karena memang sangat tepat untuk mengkaji ayat-ayat Al-Qur'ân yang berkaitan erat dengan membangun pendidikan keluarga di atas pundi-pundi Rabbaniyyah menggunakan metode maudhu'i, yang mana metode maudhu'i diartikan oleh ulama zaman sekarang menghimpun ayat-ayat Al-Qur'ân yang mempunyai maksud sama dalam arti sama-sama membicarakan satu topik masalah dan menyusunnya berdasarkan kronologis serta sebab turunnya ayat-ayat tersebut, dalam hal ini yang berkaitan erat dengan pendidikan keluarga Rabbaniyyah.

Walaupun demikian, ketika mengalami kesulitan dengan metode maudhu'i, maka penulis mencari jalan keluar yang tetap berkaitan dengan metode maudhu'i. Hal ini penulis tempuh dengan alasan berikut:

Pertama, dalam buku Kenabian (Nubuwah) dalam Al-Qur'ân ditemukan informasi. Seiring dengan kebutuhan untuk menjawab persoalan-persoalan kekinian yang tidak dijelaskan secara eksplisit di dalam Al-Qur'ân, langkah-langkah dalam metode maudhu'i tidak sepenuhnya dipedomani. Banyak persoalan yang tidak ditemukan penjelasannya secara tersurat dalam Al-Qur'ân mesti dapat memetik petunjuk yang tersirat dibalik itu. Keinginan kuat untuk menjawab pelbagai persoalan kemasyarakatan terkadang 'memaksa' tim penyusun untuk keluar dari pakem tafsir tematik. ${ }^{3}$

Kedua, dalam buku Khazanah Tafsir Indonesia dari Hermeneutika hingga Ideologi karya Islah Gusmian, ditemukan sebuah pernyataan tidak dipakainya teori al-Farmawi, karena teori itu, di samping menyimpan kerancuan dalam arah analisis, juga tidak mampu menyingkap keragaman teknis penulisan dan hermeneutika tafsir

2 Moh. Nazir, Metode Penelitian (Jakarta: Ghalia Indonesia, 1988), 63.

${ }^{3}$ Muchlis M Hanafi, dkk., Kenabian (Nubuwwah) dalam Al-Qur'ân, cet. 1 (Jakarta: Lajnah Pentashihan Mushhâf Al-Qur'ân Badan Litbang dan Diklat Kementrian Agama RI, 2012), XXXII. 
yang berkembang, apalagi menyingkap ideologi yang terselip di dalamnya, tema-tema serta wacana yang dikembangkan." ${ }^{4}$ Oleh sebab itu, setelah penulis analisa dalam penulisan jurnal ini, teori metode maudhu'i yang penulis pakai adalah metode maudhu'i merujuk kepada pendapat hasil musyawarah para ulama Al-Qur'an, tanggal 14-16 Desember 2006, di Ciloto yang terdapat pada buku Kenabian (Nubuwwah) dalam Al-Qur'ân. Kemudian ketika terjadi kesulitan, penulis mencari solusi lain, sebagaimana disebutkan pada buku tersebut.

Adapun langkah-langkah penerapan metode maudhu'i dalam pendapat lain, yang penulis nukil dalam buku Kenabian (Nubuwwah) dalam Al-Qur'ân, yang merupakan hasil musyawarah para ulama Al-Qur'ân, tanggal 14-16 Desember 2006, di Ciloto, adalah sebagai berikut:

1. Menentukan topik atau tema yang akan dibahas.

2. Menghimpun ayat-ayat menyangkut topik yang akan dibahas.

3. Menyusun urutan ayat sesuai masa turunnya.

4. Memahami korelasi (munasabah) antar ayat.

5. Memperhatikan sebab nuzul untuk memahami konteks ayat.

6. Melengkapi pembahasan dengan hadis-hadis dan pendapat para ulama.

7. Mempelajari ayat-ayat secara mendalam.

8. Menganalisis ayat-ayat secara utuh dan komprehensif dengan jalan mengkrompomikan antara yang 'am dan khas, yang mutlaq dan muqayad dan lain sebagainya.

9. Membuat kesimpulan dari masalah yang dibahas. ${ }^{5}$

Dari beberapa informasi di atas, tentunya sangat membantu penulis dalam penulisan jurnal ini, agar lebih terarah dalam memecahkan masalah yang akan dibahas, sehingga menghasilkan pembahasan yang lebih sempurna dan dapat bermanfaat, khususnya bagi penulis dan umumnya bagi para pembaca. Pembahasan membangun pendidikan keluarga di atas pundi-pundi Rabbaniyyah menurut hemat penulis amat penting untuk disajikan, melihat kondisi dan situasi bangsa Indonesia saat ini sedang mengalami kerusakan mental spiritual, perlu kiranya memahami kembali prinsip-prinsip dasar pendidikan yang diabadikan dalam Al-Qur'ân sebagai pijakan dan menata jalan hidup menuju keselamatan dunia dan akhirat.

\section{Jenis dan Sumber Data}

Di dalam penelitian, dikenal berbagai macam jenis penelitian data. Berdasarkan kemungkinan analisis dan pengukurannya, data dapat dibedakan atas data kualitatif dan data kuantitatif. Jenis data dalam penelitian ini termasuk jenis data

\footnotetext{
4 Islah Gusmian, Khazanah Tafsir Indonesia dari Hermeneutika hingga Ideologi, 33.

${ }^{5}$ Muchlis M Hanafi, dkk., Kenabian (Nubuwwah) dalam Al-Qur'ân, XXXII.
} 
kualitatif yang terdiri dari kata-kata atau konsep-konsep pemikiran yang tertuang dalam berbagai literatur kitab-kitab, buku dan dokumentasi tertulis lainnya.

Sebagaimana telah dikemukakan di atas, bahwa penelitian ini termasuk penelitian kepustakaan (library research) yang datanya diperoleh dari sumber data tertulis yang terkait langsung atau tidak langsung dengan topik bahasan. Ada dua sumber data yang dijadikan landasan dalam penelitian ini yaitu sumber data primer dan sumber data sekunder. Yang dimaksud dengan sumber data primer di sini adalah sumber data yang diperoleh langsung dari ayat-ayat Al-Qur'ân. Topik penelitian yang dikaji ini sangat berkaitan erat dengan ayat-ayat Al-Qur'ân, maka sumber data primer dalam penelitian ini adalah ayat-ayat Al-Qur'ân.

Adapun sumber data sekunder dalam penelitian ini adalah sumber kedua yang sangat menunjang sumber data primer yaitu sumber data yang terdapat dalam kitab-kitab tafsir yang dibatasi pada beberapa kitab tafsir yang dianggap representatif. Di antara kitab-kitab tafsir yang dijadikan rujukan dalam penelitian ini adalah: 1) Tafsîr al-Mishbâh, karya M Quraish Shihab, dengan alasan yang paling utamanya adalah karena M Quraish Shihab merupakan sosok mufasir Indonesia yang handal, sekaligus memahami tatabahasa Arab yang mendalam. 2) Tafsîr al-Munîr fì al-'Aqidah wa asy-Syarî'ah wa al-Manhâj karya Wahbah Mushtafa az-Zuhaily, 3) Jâmi' al-Bayân 'an Ta'wil Ayi Al-Qur'ân, dan 4) Tafsîr asy-Sya'râwî̀, karya Muhammad Mutawali asy-Sya'râwî.

Sedangkan sumber-sumber lainnya adalah Terjemahan Al-Qur'ân Al-Karîm yang diterbitkan Mujama' Malik al-Fahd, Madinah, 1418 H. Untuk mempermudah pencarian terhadap ayat-ayat Al-Qur'ân yang diperlukan dalam pembahasan ini, penulis menggunakan kitab Mu'jam al-Muhfaras li Alfadl Al-Qur'ân, karya Muhammad Fuad 'Abd al-Baqi. Juga sumber lainnya adalah buku-buku yang berkaitan erat dengan pembahasan dalam penelitian ini, seperti Character Matters How to Help Our Children Develop Good Judgment Integrity and Other Essential Virtues, karya Thomas Lickona, Charakter Building, karya Ngainun Naim, Konsep dan Model Pendidikan Karakter, karya Muchlas Samani dan Hariyanto, dan lain-lain.

\section{HASIL DAN PEMBAHASAN}

Memang tidak mudah untuk melacak ayat-ayat Al-Qur'ân yang berkaitan dengan pembahasan mengenai faktor-faktor yang membentuk kepribadian (karakter). Namun penulis mencoba untuk melacaknya, di mana ada sebuah ayat Al-Qur'ân yang penulis anggap sangat berkaitan erat dengan pembahasan mengenai faktor pembentuk kepribadian (karakter) manusia, yaitu pada firman Allah swt surah Ar-Rûm/30 ayat 30:

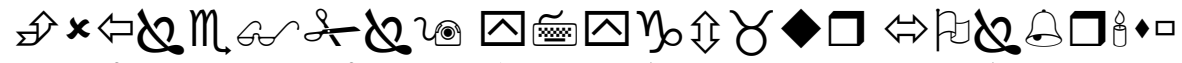

$$
\begin{aligned}
& \text { कि }
\end{aligned}
$$

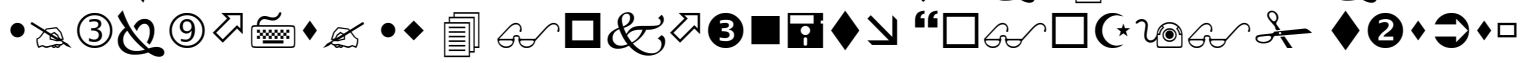

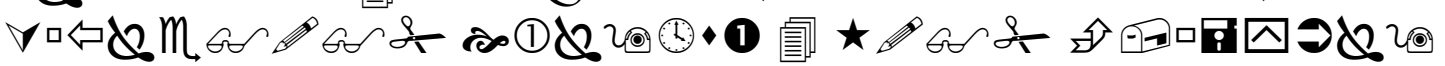




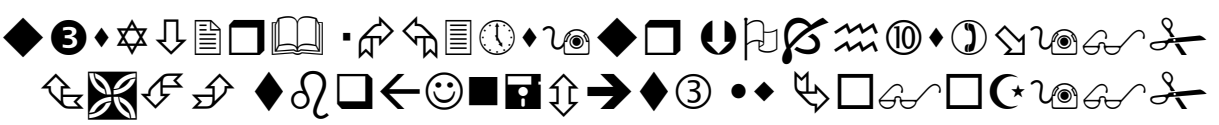

Maka hadapkanlah wajahmu dengan lurus kepada agama Allah; (tetaplah atas) fitrah Allah yang telah menciptakan manusia menurut fitrah itu. tidak ada perubahan pada fitrah Allah. (Itulah) agama yang lurus; tetapi kebanyakan manusia tidak mengetahui.

Pada ayat di atas, memberikan informasi bahwa Allah swt telah menciptakan manusia sesuai dengan fitrahnya, yaitu setiap manusia yang lahir ke dunia ini membawa potensi yang baik (positif). Di mana manusia dilahirkan ke alam dunia ini dalam keadaan suci, tanpa membawa noda dan dosa. Dan untuk lebih jelasnya mengenai uraian fitrah manusia pada ayat di atas, yang penulis anggap sebagai faktor pembentuk kepribadian (karakter) manusia, maka di bawah ini penulis menukil beberapa pendapat para mufasir, sebagai berikut:

Dalam Tafsîr al-Mishbâh, M Quraish Shihab memberikan keterangan bahwa kata fitrah adalah mencipta sesuatu pertama kali/tanpa ada contoh sebelumnya atau dapat dipahami pula dalam arti asal kejadian, atau bawaan sejak lahir. Ada juga yang berpendapat bahwa fitrah yang dimaksud adalah keyakinan tentang keesaan Allah swt, yang telah ditanamkan Allah swt dalam diri setiap manusia (insan). Atau fitrah adalah ciptaan pertama dan tabiat awal yang Allah swt ciptakan manusia atas dasarnya. ${ }^{6}$

Muhammad Mutawali Asy-Sya'râwî dalam tafsirnya Tafsr asy-Sya'râwî̀ memberikan keterangan mengenai fitrah sebagai berikut: "Al-fithrah adalah pembawaan sejak lahir (ath-thabî'ah) yang Allah swt ciptakan menjadi satu semenjak Allah swt menciptakan Adam as dan Allah swt menciptakan dari Adam as, keturunan dan mereka bersaksi atas diri mereka untuk mengakui bahwa Allah swt adalah Tuhan mereka". ${ }^{7}$ Dalam At-Tafsîr al-Munîr karya Wahbah Mushthafâ az-Zuhaili diberikan informasi bahwa: Fitrah adalah ciptaan Allah swt yang diberikan kepada manusia berupa perasaan (filing) yang diarahkan untuk beribadah kepada Allah swt dan menerima kebenaran serta mengetahuinya, mengesakan Allah swt yang tiada Tuhan selain-Nya". ${ }^{8}$

Dari beberapa pendapat mufasir di atas, pada intinya memberikan penjelasan yang sama dalam arti bahwa Allah swt memberikan potensi kepada manusia untuk menjadi manusia yang bersih sesuai fitrahnya, yaitu sejak awal diciptakan manusia mengakui bahwa Allah swt sebagai Tuhan yang menciptakannya dan akan selalu beribadah kepada-Nya. Semua manusia yang hidup di alam dunia ini, pada saat dilahirkan melalui wasilah hubungan intim ibu dan bapaknya membawa fitrah yang suci bersih dan mengakui keesaan Allah swt sebagai Tuhannya, menerima kebenaran dan mengetahui kebenaran itu sendiri. Akan tetapi, dengan berjalannya waktu

\footnotetext{
${ }^{6}$ M Quraish Shihab, Tafsîr al- Mishbâh, Vol. 11 (Jakarta: Lentera Hati, 2003), 53.

7 Muhammad Mutawali Asy-Sya'râwî, Tafsîr asy-Sya'râwwî, Jilid. 18 (Kairo: Idarah al-Kutub wa al-Maktabat, 1991), 11418.

8 Wahbah Mushthafâ Az-Zuhaili, At-Tafsîr al-Munîr, Cet. 2 (Beirut: Dâr al-Fikr, 2005), 87.
} 
manusia banyak yang melupakan fitrah tersebut, sehingga manusia jauh dari kebenaran, bahkan yang menjadi masalah utama adalah sudah tidak menjadikan kitab suci Al-Qur'an sebagai rujukan kehidupan, yang mengakibatkan kebanyakan manusia saat ini sudah melupakan fitrah yang Allah swt anugerahkan kepada manusia.

Kemudian kita juga mengenal tentang fithrah ini dalam hadits yang sangat popular, yaitu sabda Nabi Muhammad saw yang diriwayatkan oleh Al-Bukhari dan Muslim:

$$
\text { كل مولد يولا على الفطرة, فأبو اه يهوّدانه أوينصّر انه أويمجّسانه, ؟9 }
$$

Setiap manusia dilahirkan dalam keadaan fithrah (suci), maka tergantung kepada kedua orang tuanya, apakah mau dijadikan Yahudi atau Nasrani atau Majusi?

Dari penjelasan dua sumber di atas, yaitu Al-Qur'ân Al-Karim dan Al-Hadits dapat dipahami, bahwa pada prinsipnya fitrah itu asalnya bersih murni merupakan anugerah dari Allah swt, namun dengan berjalannya waktu, termasuk lingkungan sangat mempengaruhi keberadaan seseorang. Sebagaimana dijelaskan pada hadits di atas, anak yang baru lahir, awalnya dalam keadaan fitrah/suci/bersih, akan tetapi kedua orang tuanya yang menjadikan ia sebagai Yahudi, Nasrani, atau Majusi. Juga yang menjadi masalah adalah anak yang dilahirkan dalam keluarga yang beragama Islam, apakah ia tetap Islam atau hanya sebatas Islam keturunan, sehingga pada kenyataannya sekarang banyak umat Islam yang tidak lagi menjaga fitrahnya, dikarenakan tertipu oleh kehidupan dan kecintaan terhadap dunia yang berlebihan. Ia lupa pada kejadian semula, dalam keadaan fitrah dan berjanji akan selalu berbuat baik dalam rangka beribadah kepada Allah swt dalam pengertian yang luas.

Sehingga kalau ditelaah secara saksama, bahwa faktor-faktor yang membentuk kepribadian (karakter) itu supaya tetap dalam posisi fitrah, maka bukan hanya sekadar beragama Islam karena dilahirkan dari kalangan Islam, akan tetapi harus berusaha memahami ajaran Islam yang sebenarnya, dan berusaha mengaplikasikan dalam realita kehidupan. Mulai berupaya dan berusaha agar mampu membaca Al-Qur'an secara baik dan benar, memahami isi kandungan Al-Qur'an dan berusaha mengamalkannya dalam kehidupan nyata, di mana setiap gerak dan langkahnya mencerminkan bagaikan Al-Qur'an berjalan di muka bumi.

\section{Profil Manusia Berkepribadian (Berkarakter)}

Manusia yang berkepribadian (berkarakter) adalah manusia yang dalam prilaku dan segala hal yang berkaitan dengan aktivitas hidupnya sarat dengan nilai-nilai kebaikan. Manusia semacam ini bukan berarti tidak pernah melakukan kesalahan, tetapi selalu berusaha memperbaiki segala bentuk kesalahannya dan terus

9 Ibnu Hajar Al-'Asqalani, Fath al-Bâri fî Shahîh al-Bukhari, Jilid. 3 (Mesir: Maktabah Mishr, 2001), 254. 
menerus memperbaiki diri dari waktu ke waktu. ${ }^{10}$ Kriteria semacam ini memang masih terlalu abstrak dan general. Maka, ketika diterjemahkan ke tataran aplikatif untuk mengetahui karakteristiknya menjadi sulit. Setiap orang akan memiliki kriteria dan pandangan sendiri-sendiri, sesuai latar belakang keilmuan dan landasan berpikirnya. Hal ini wajar karena memang tidak ada kriteria tunggal yang disepakati oleh semua orang.

Kepribadian (Karakter) sendiri pada dasarnya harus disesuaikan dengan kondisi sosial, nilai moral dan berbagai nilai-nilai yang khas yang ada pada sebuah daerah. ${ }^{11}$ Dari pengertian di atas, pada prinsipnya kepribadian (karakter) dalam arti yang sebenarnya adalah Kepribadian (karakter) yang mengacu pada ajaran agama Islam, sementara pendapat di atas masih bersifat umum, bahkan disebutkan bahwa kepribadian (karakter) harus disesuaikan dengan kondisi sosial dan nilai moral daerah tertentu. Artinya bahwa ajaran agama Islam merupakan ajaran yang universal, tentunya akan memberikan solusi setiap permasalahan yang dihadapi oleh manusia di mana pun berada. ${ }^{12}$ Sedangkan menurut Thomas Lickona dalam bukunya "Character Matters", ada derajat konsensus yang sangat tinggi pada lima kriteria sebagai contoh, yaitu: (1) komitmen yang kokoh pada idaman-idaman moral; (2) konsistensi antara idaman-idaman seseorang dan cara untuk mencapainya; (3) kesediaan untuk mengorbankan kepentingan diri sendiri; (4) kemampuan untuk mengilhami orang lain; (5) kerendahan hati tentang pentingnya pribadi seseorang". ${ }^{13}$

Demikian pula, menurut Abrahah maslow, manusia yang berkualitas (berkepribadian/karakter) adalah manusia yang mampu mengaktualisasikan diri, yaitu manusia yang memiliki karakteristik, sebagai berikut: Dapat menerima dirinya, orang lain, dan lingkungan sekitar. (2) Berpandangan realistik. (3) Tidak bersikap pasrah (pasif). (4) Berorientasi pada problem-problem eksternal. (6) Mengapresiasi kebebasan dan kebutuhan akan spesialisasi. (7) Berkepribadian independen dan bebas dari pengaruh orang lain. (8) Mengapresiasi segala sesuatu secara progresif, tidak terjebak pada pola-pola baku. (9) Integrative dan akomodatif terhadap semua kalangan. (10) Hubungan dengan orang lain sangat kuat dan mendalam, bukan sekadar formalitas. (11) Arah dan norma demokratisnya diliputi oleh sikap toleran dan sensitivitasnya. (12) Tidak mencampuradukkan antara sarana dan tujuan. (14) Gemar mencipta, berkreasi, dan menemukan penemuan-penemuan skala besar. (15)

\footnotetext{
10 Ngainun Naim, Karakter Building Optimalisasi Peran Pendidikan dalam Pengembangan Ilmu $\mathcal{E}$ Pembentukan Karakter Bangsa, 60.

11 Ngainun Naim, Karakter Building Optimalisasi Peran Pendidikan dalam Pengembangan Ilmu E Pembentukan Karakter Bangsa, 60.

12 Saihu, Pendidikan Karakter Berbasis Kearifan Lokal (Studi Di Jembrana Bali)", Edukasi Islami: Jurnal Pendidikan Islam, Vol: 08, No: 01 (2019): 69-90.

13 Thomas Lickona, Character Matters How to Help Our Children Develop Good Judgment, Integrity, and Other Essential Virtues (New York: Touchstone Rockefeller Center, 2004), 21.
} 
Menentang ketaatan dan kepatuhan buta terhadap budaya. (16) Berjiwa riang secara filosofis, tidak bermusuhan. ${ }^{14}$

Dari penjelasan di atas, mengenai profil manusia berkepribadian/berkarater masih bersifat umum dan tidak mudah untuk memahaminya. Oleh sebab itu, betapa pentingnya untuk memahami profil manusia yang berkepribadian/berkarakter sebagai acuan dalam menempuh kehidupan ini, dikala kebanyakan manusia sudah melupakan tujuan hidup yang sebenarnya karena terpengaruh dengan kehidupan dunia, termasuk saat ini yang dialami bangsa Indonesia.

Maka pada bagian ini, penulis memandang penting untuk menampilkan dua profil manusia teladan utama, di mana kedua tokoh utama tersebut adalah Nabi Muhammad saw dan Nabi Ibrâhîm as. Di mana implementasi akhlak dalam Islam tersimpul dalam kepribadian/karakter pribadi Nabi Muhammad saw. Dalam pribadi Nabi Muhammad Saw, bersemai nilai-nilai akhlak yang mulia dan agung. Hal ini dijelaskan melalui Al-Qur'ân dalam surah Al-Ahzâb/33 ayat 21 menyatakan :

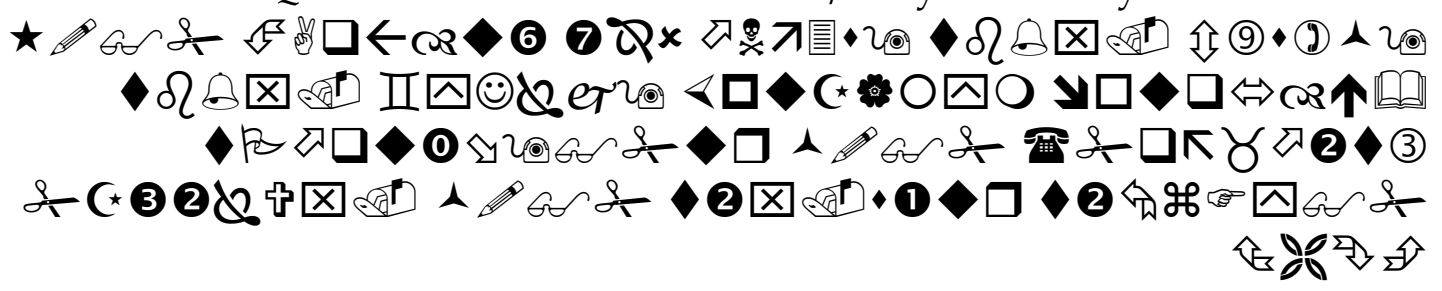

Sesungguhnya telah ada pada (diri) Rasulullah itu suri teladan yang baik bagimu (yaitu) bagi orang yang mengharap (rahmat) Allah dan (kedatangan) hari kiamat dan dia banyak menyebut Allah.

Dalam suatu hadis juga dinyatakan, bahwa Nabi Muhammad Saw, bersabda:

$$
\text { إنّما بعثت لأتمم صلا ح الأخلاق (رواه أحمد)15 }
$$

Sesungguhnya aku diutus di dunia ini tak lain untuk menyempurnakan akhlak budi pekerti yang mulia.

Demikian pula, pada pribadi Nabi Ibrâhîm as, merupakan contoh teladan utama, sebagaimana diabadikan dalam firman Allah swt, pada surah Al-Mumtahanah/60 ayat $4-6$ :

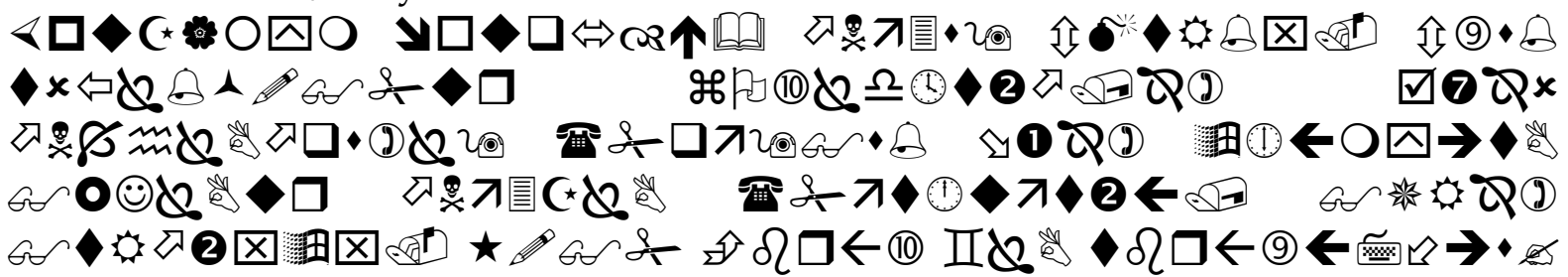

14 Ngainun Naim, Karakter Building Optimalisasi Peran Pendidikan dalam Pengembangan Ilmu E Pembentukan Karakter Bangsa, 61.

15 Ahmad bin Muhammad bin Hanbal, Al-Musnad, Cet. 1, (Mesir: Dâr al-Hadits, 1995), 56. 


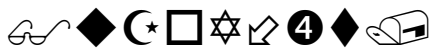

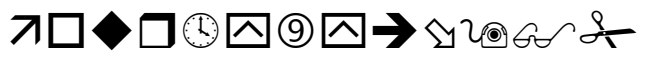

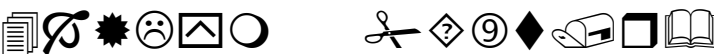

\& $\triangle(9) \leftrightarrow \square$

र

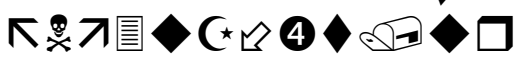

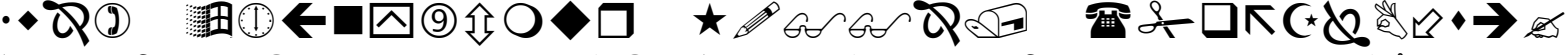

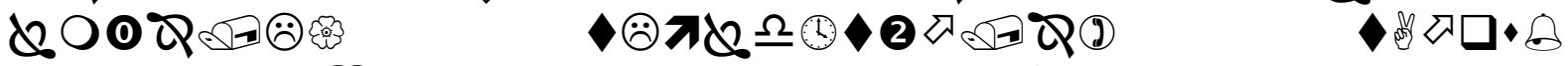

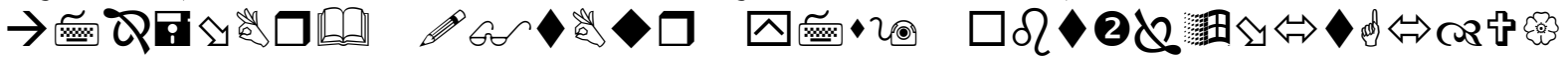

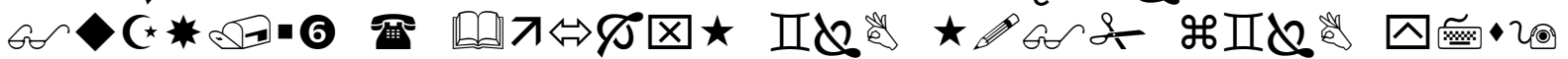

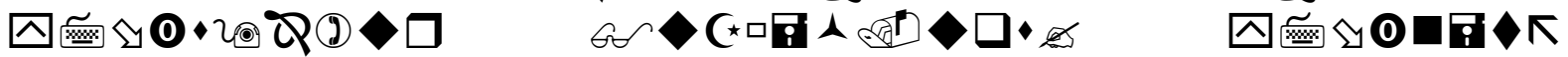

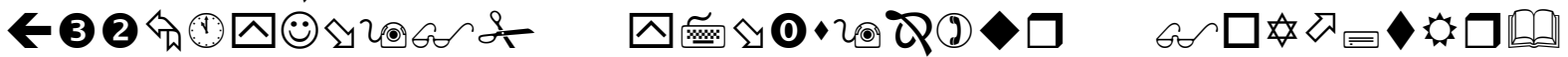

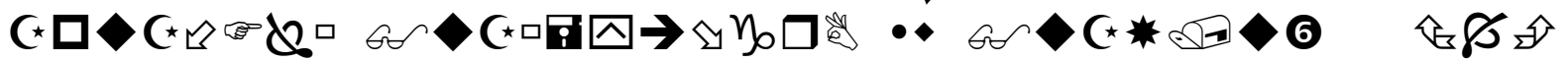

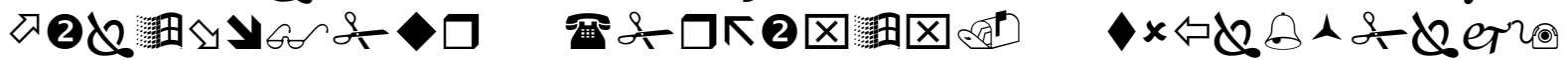

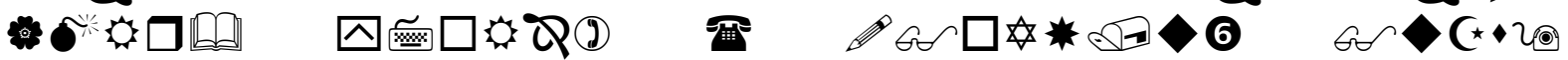

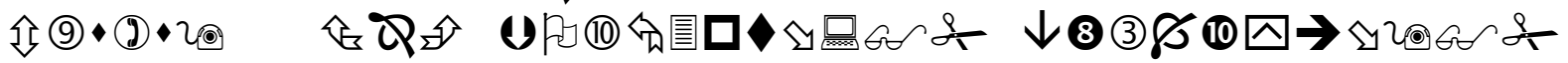

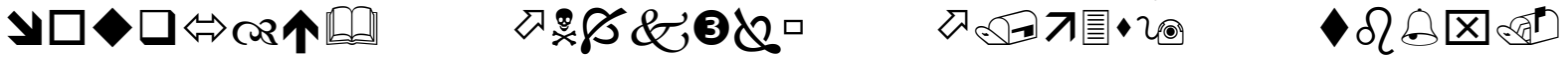

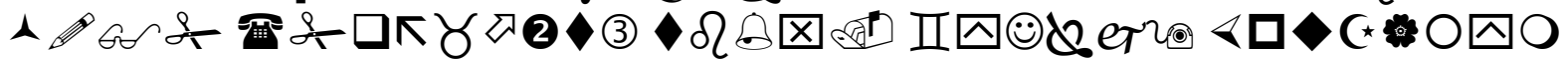
○

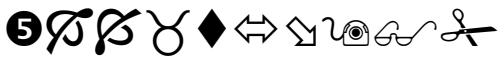

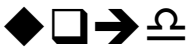

10 ar \& $\square \Omega Q \nabla \square$

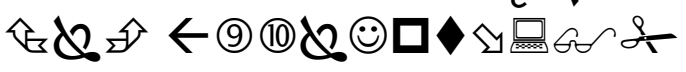

Sesungguhnya telah ada suri tauladan yang baik bagimu pada Ibrâhîm dan orang-orang yang bersama dengan dia; ketika mereka berkata kepada kaum mereka: "Sesungguhnya kami berlepas diri daripada kamu dan daripada apa yang kamu sembah selain Allah, kami ingkari (kekafiran)mu dan telah nyata antara kami dan kamu permusuhan dan kebencian buat selama-lamanya sampai kamu beriman kepada Allah saja. Kecuali perkataan Ibrâhîm kepada bapaknya: "Sesungguhnya aku akan memohonkan ampunan bagi kamu dan aku tiada dapat menolak sesuatupun dari kamu (siksaan) Allah". (Ibrâhîm berkata): "Ya Tuhan kami hanya kepada Engkaulah kami bertawakkal dan hanya kepada Engkaulah kami bertaubat dan hanya kepada Engkaulah kami kembali." "Ya Tuhan kami, janganlah Engkau jadikan kami (sasaran) fitnah bagi orang-orang kafir. dan ampunilah kami Ya Tuhan kami. Sesungguhnya Engkaulah yang Maha Perkasa lagi Maha Bijaksana". Sesungguhnya pada mereka itu (Ibrâhîm dan umatnya) ada teladan yang baik bagimu; (yaitu) bagi orang-orang yang mengharap (pahala) Allah dan (keselamatan pada) hari kemudian. dan barangsiapa yang berpaling, maka sesungguhnya Allah Dia-lah yang Maha Kaya lagi Maha Terpuj.

Dari dua profil tokoh besar sepanjang sejarah ini, yaitu Nabi Muhammad saw dan Nabi Ibrâhîm as, kiranya sangat perlu untuk dipelajari dan dipahami dengan baik dan secara mendalam, kemudian dijadikan contoh dan diaplikasikan dalam kehidupan sehari-hari. Apalagi melihat kondisi saat ini di negeri tercinta Indonesia yang sedang mengalami krisis kepemimpin, yang diakibatkan krisis akidah dan krisis akhlak (moral) yang menjadi pemicu krisis-krisis lainnya, termasuk krisis ekonomi. 
Untuk memahami lebih dalam mengenai dua tokoh besar tersebut, walaupun pada penulisan jurnal ini, penulis fokuskan kepada kepribadian/karakter manusia dalam Al-Qur'ân membangun pendidikan keluarga di atas pundi-pundi Rabbaniyyah, hanya sedikit membahas tentang kisah Nabi Muhammad saw dan Ibrahim as. Di mana pada dasarnya kedua tokoh dalam sejarah manusia ini, tidak bisa dipisahkan antara keduanya, sebagai tokoh sentral dalam kehidupan manusia, sehingga kedua nama besar tersebut diabadikan secara khusus pada rangkaian ibadah salat.

\section{Kepribadian (Karakter) para Nabi dan Rasul}

Sebelum menjelaskan tentang kepribadian/karakter para Nabi dan rasul, perlu kiranya mengetahui daripada fungsi para Nabi dan Rasul diutus Allah swt ke dunia ini. Secara garis besar, fungsi para Nabi dan Rasul diutus Allah swt kepada umat manusia dengan membawa beberapa tugas utama, sebagaimana penulis kutip dalam buku Kenabian (nubuwwah) dalam Al-Qur'ân, yaitu:16

1. Sebagai saksi kepada semua manusia mengenai kebenaran rohani yang masih tertutup oleh kebodohan, takhayul dan pertentangan golongan. Kedatangannya bukan membawa agama baru, melainkan untuk mengajarkan agama yang sebenarnya. Ia juga menjadi saksi dihadapan Allah swt atas segala perbuatan manusia dan bagaimana mereka menerima ajaran Allah swt.

2. Sebagai pembawa berita gembira berupa rahmat dari Allah swt. Harapan selalu ada bila manusia beriman, bertobat dan hidup dengan cara yang baik.

3. Sebagai pemberi peringatan kepada mereka yang lalai, hidup tidak berakhir hanya sampai di dunia, melainkan masih ada kehidupan akhirat yang sangat penting.

4. Sebagai orang yang mempunyai hak untuk mengajak semua manusia untuk bertobat dengan izin dan wewenang yang diberikan Allah swt kepadanya.

5. Sebagai cahaya atau pelita; cahaya Islam sebagai karunia terbesar yang akan menerangi dunia.

Dari penjelasan di atas, jelas sekali bahwa fungsi diutusnya para Nabi dan Rasul oleh Allah swt adalah untuk menjadi saksi atas segala perbuatan umat manusia yang dilakukan ketika hidup di dunia ini, akan diminta pertanggung jawabannya kelak di akhirat nanti. Juga sebagai pemberi berita gembira bagi orang yang beriman dan beramal saleh dan pemberi peringatan bagi manusia yang melakukan penyimpangan-penyimpangan atau kesalahan-kesalahan dan dosa-dosa, akan diberikan siksa yang pedih di akhirat, ketika di dunia tidak mau bertobat. Juga berfungsi sebagai cahaya atau pelita, bahwa ajaran yang dibawa oleh para Nabi dan Rasul memberikan arahan menuju jalan yang benar lagi lurus, yang diridhai Allah Swt.

16 Muchlis M Hanafi, dkk., Kenabian (nubuwwah) dalam Al-Qur'ân, cet. 1 (Jakarta: Lajnah Pentashhihan Mushhâf Al-Qur'ân, 2012), 40-41. 
Adapun kepribadian/karakter para Nabi dan Rasul yang diabadikan Al-Qur'ân, baik secara eksplisit maupun derivasinya adalah shiddiq (selalu benar dalam sikap, ucapan dan perbuatannya), amanah (dapat dipercaya, jujur dan terhindar dari sifat khianat), tabligh (menyampaikan wahyu yang telah diterima seorang nabi, baik berupa perintah maupun larangan kepada umatnya), dan fathanah (bijaksana, cerdas, serta terhindar dari sifat al-jahl, bodoh, tolol, apalagi dungu). ${ }^{17}$

Di samping kepribadian/karakter di atas, tentunya masih ada yang lainnya secara khusus diabadikan dalam Al-Qur'ân, di antaranya yaitu: al-muhsinîn, ${ }^{18}$ ash-shalihîn, ${ }^{19}$ fadhalnâ 'ala al-'Ălamîn, ${ }^{20}$ ash-shabirîn, ${ }^{21}$ al-mukhlashîn. ${ }^{22}$

\section{Kepribadian (Karakter) Manusia yang Baik}

${ }_{17}$ Muchlis M Hanafi, dkk, Kenabian (nubuwwah) dalam Al-Qur'ân, 66.

${ }^{18}$ Lihat Q.S. Al-An'âm/6 ayat 84, hal. 138. Kata Al-muhsinîn adalah jamak dari kata muhsin. Kata ihsan adalah puncak kebaikan amal. Perbuatan ihsan terhadap seorang hamba tercapai saat seseorang memandang dirinya pada diri orang lain, sehingga ia memberi untuknya yang seharusnya dia beri untuk dirinya, sedang ihsan antara hamba dengan Allah swt adalah leburnya dirinya, sehingga dia hanya "melihat" Allah swt. Karena itu pula ihsan antara hamba dengan sesama manusia adalah bahwa dia tidak melihat lagi dirinya dan hanya melihat orang lain itu. Siapa melihat dirinya pada posisi kebutuhan orang lain dan tidak melihat dirinya pada saat beribadah kepada Allah swt, maka dia itulah dinamai muhsin, dan ketika itu dia mencapai puncak dalam segala amalnya. $\mathrm{M}$ Quraish Shihab, Tafsir al-Mishbah, 199.

19 Lihat Q.S. Al-An'âm/6 ayat 85, hal. 138. ash-shalihîn adalah orang-orang yang gemar melaksanakan atau melakukan amal saleh, yaitu amal yang baik, tidak rusak, tidak binasa, patut, bermanfaat, dan damai. Ash-shalihîn adalah pribadi-pribadi yang tidak semata-mata melaksanakan perintah dan meninggalkan larangan Allah swt, lebih dari itu mereka secara berkesinambngan dan konsisten melaksanakan yang disunnahkan-Nya. Hal ini merupakan pertanda bahwa dalam diri orang saleh terdapat sifat-sifat yang indah dan mulia, termasuk di dalamnya mawadah (cinta kasih) yang terbebas dari berbagai bentuk kedengkian. Slamet Firdaus, Konsep Manusia Ideal dalam Al-Qur'ân, 115.

${ }^{20}$ Lihat Q.S. Al-An'âm/6 ayat 86, hal. 138. fadhalnâ 'alâ al-'Ălamîin

${ }^{21}$ Lihat Q.S. Ash-Shâffât/37 ayat 102, hal. 449. Kata ash-shabirîn berasal dari kata ash-shabr/sabar yang dimaksud banyak hal, sabar mengahadapi ejekan dan rayuan, sabar melaksanakan perintah dan menjauhi larangan, sabar dalam petaka dan kesulitan, serta sabar dalam berjuang menegakkan kebenaran dan keadilan. Kesabarana membawa kepada kebaikan dan kebahagiaan, maka manusia tidak boleh berpangku tangan, atau terbawa kesedihan oleh petaka yang dialaminya, ia harus berjuang dan berjuang. Memperjuangkan kebenaran dan menegakkan keadilan, dapat mengakibatkan kematian. Puncak petaka yang memerlukan kesabaran adalah kematian. $\mathrm{M}$ Quraish Shihab, Tafsir al-Mishbah, 339-340.

${ }^{22}$ Lihat Q.S. Ash-Shâffât (37) ayat 40, 128, 160, 169. Kata al-mukhlashîn ada juga yang membaca al-mukhlishîn terambil dari kata khalusha yang berarti murni tidak bercampur lagi dengan sesuatu yang tadinya mengotorinya. Dari sini lahir kata ikhlash yang berarti kemurnian hati, dan aktivitas yang hanya tertuju kepada Allah swt semata-mata tanpa bercampur dengan sesuatu selain-Nya yang dapat mengotori amalan yang dikerjakan itu. Al-mukhlishîn berarti hamba-hamba Allah swt yang melakukan aktivitasnya secara ikhlas demi karena Allah swt dan al-mukhlashîn berarti yang dipilih dan dipisahkan Allah swt dari hamba-hamba-Nya yang lain dan yang dijadikan khusus buat diri-Nya sendiri. Mereka tidak tergiur lagi oleh apapun dari kenikmatan duniawi dan hanya mengarah semata-mata kepada Allah swt. M Quraish Shihab, Tafsir al-Mishbah, 31-32. 
Kepribadian/karakter manusia yang baik di dalam Al-Qur'ân paling tidak ada delapan kepribadian/karakter yang sangat populer, serta menjadi bagian utama sebagai lambang kedekatan hubungan manusia dengan Sang Pencipta Allah swt. Di mana pada bagian ini akan dijelaskan mengenai kepribadian/karakter manusia dalam Al-Qur'ân, yang menjadi dasar sebagai pembangun pendidikan keluarga di atas pundi-pundi Rabbaniyyah.

Sembilan kepribadian/karakter yang baik tersebut diabadikan dalam Al-Qur'ân, yang mana kepribadian/karakter ini merupakan sebuah pernyataan yang sangat tegas langsung dari Allah swt, bahwa Allah swt benar-benar mencintai mereka, yaitu sebagai berikut:

1. Al-muttaqîn (orang-orang yang bertakwa)

Surah Ăli 'Imrân/3 ayat 76,

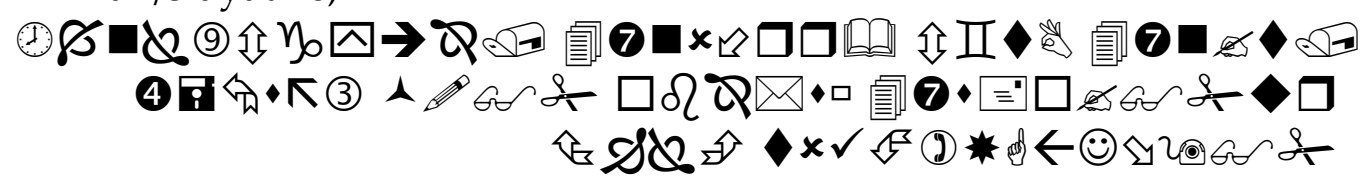

(Bukan demikian), sebenarnya siapa yang menepati janji (yang dibuat)nya dan bertakwa, maka sesungguhnya Allah menyukai orang-orang yang bertakwa.

Dalam Tafsîr al-Mishbâh, M Quraish Shihab memberikan keterangan sebagai

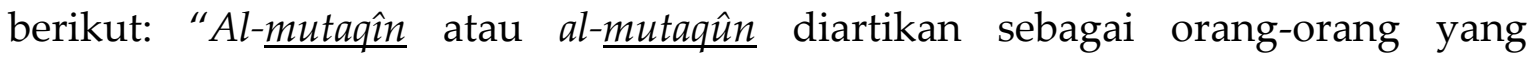
bertakwa. Orang yang bertakwa adalah orang yang mempersiapkan diri jiwa mereka untuk menerima petunjuk atau yang telah mendapatkannya tetapi masih mengharapkan kelebihan, karena petunjuk Allah swt tidak terbatas. Takwa juga berarti menghindar, orang bertakwa adalah orang yang menghindar dari tiga tingkat penghindaran, yaitu menghindar dari kekufuran dengan jalan beriman kepada Allah Swt, berupaya melaksanakan perintah Allah Swt sepanjang kemampuan yang dimiliki dan menjauhi larangan-Nya, menghindar dari segala aktivitas yang menjauhkan pikiran dari Allah swt." 23

Dalam referensi lain' :Al-mutaqîn atau al-mutaqûn merupakan jama' dari kata mutaqa-wal itiqâu minal wiqâyah, wal wiqâyah hiya al-Ihtirâs wa al-Ba'id 'an asy-Syar/ menjaga diri atau hati-hati, dan kata al-Itiqâu berasal dari kata wiqâyah yang berarti perlindungan, penjagaan, pengawalan, kehati-hatian dan kewaspadaan yaitu kehati-hatian/kewaspadaan dan dijauhkan dari kejelekan/keburukan atau kejahatan, dengan jalan bertakwa kepada Allah swt serta tidak mengerjakan perbuatan yang mengantarkan kepada kemurkaan Allah swt, sehingga terhindar dari siksa api neraka. Dan berupaya meninggalkan perbuatan maksiat dan

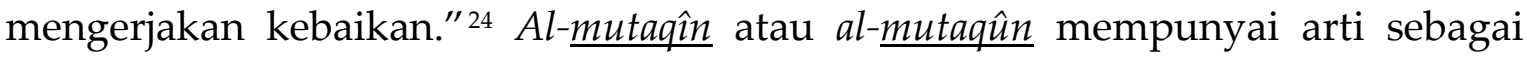
orang yang menjaga dirinya daripada hal yang membuat bahaya baginya, dengan

${ }^{23}$ M Quraish Shihab, Tafsîr al-Mishbâh, Vol. 2, 249.

${ }^{24}$ Muhammad Mutawali Asy-Sya' râwî, Tafsîr asy-Sya'râwồ, Jilid. 1, 121-122. 
berupaya melaksanakan perintah Allah swt dan berupaya untuk menjauhi terhadap segala yang dilarang-Nya." 25

Dari beberapa pendapat di atas, pada intinya bahwa al-mutaqîn atau al-mutaqûn yang diartikan sebagai orang yang bertakwa adalah orang-orang yang berupaya sekuat tenaga untuk melaksanakan perintah Allah swt dan berupaya untuk selalu menjauhi terhadap apa yang dilarang-Nya. Serta selalu berusaha menggali nilai-nilai ajaran Islam secara kafah agar segala ibadah yang dilakukannya berdasarkan pengetahuan yang benar, sehingga mengantarkan mendapat ridha Allah swt, dimasukan ke dalam Surga dan dijauhkan daripada siksa api neraka.

2. Ash-shâbirîn (orang-orang yang sabar) surah Ăli ‘Imrân/3 ayat 146,

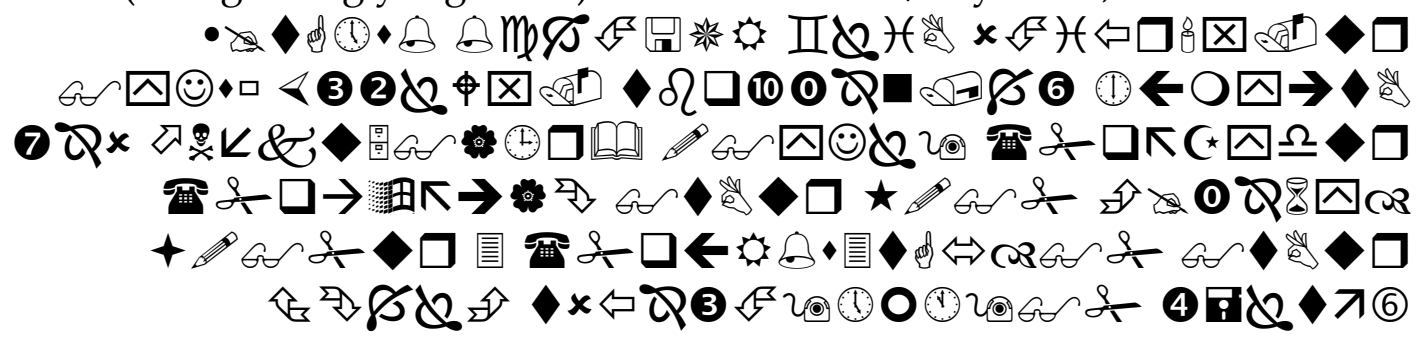

Dan berapa banyaknya Nabi yang berperang bersama-sama mereka sejumlah besar dari pengikut (nya) yang bertakwa. mereka tidak menjadi lemah karena bencana yang menimpa mereka di jalan Allah, dan tidak lesu dan tidak (pula) menyerah (kepada musuh). Allah menyukai orang-orang yang sabar.

Kata ash-shabr/sabar berarti mencegah jiwa untuk mencintai dan kenikmatan dunia yang berdasarkan hawa nafsu, dengan mengikuti ketaatan kepada Allah swt dan meninggalkan maksiat. ${ }^{26}$ Ash-shabr/sabar berarti pula kekuatan atau potensi dalam menghadapi kesulitan/kesempitan/tekanan dan penderitaan yang tidak disukai. ${ }^{27}$ Sehingga dapat dipahami bahwa sabar merupakan salah satu sifat yang baik/positif yang harus selalu dijaga, agar dalam menghadapi berbagai macam ujian/cobaan dapat melewatinya dengan baik dan sukses, khususnya dalam mengahadapi kehidupan di dunia ini menuju kehidupan akhirat yang kekal. Sabar dalam menghadapi ujian/cobaan, sabar dalam melaksanakan segala perintah Allah swt, juga sabar dalam menjauhkan diri dari pada kemaksiatan yang setiap saat berada di depan mata manusia.

3. Al-mutawakilîn (orang-orang yang bertawakal/berserah diri) surah Ăli 'Imrân/3 ayat 159 .

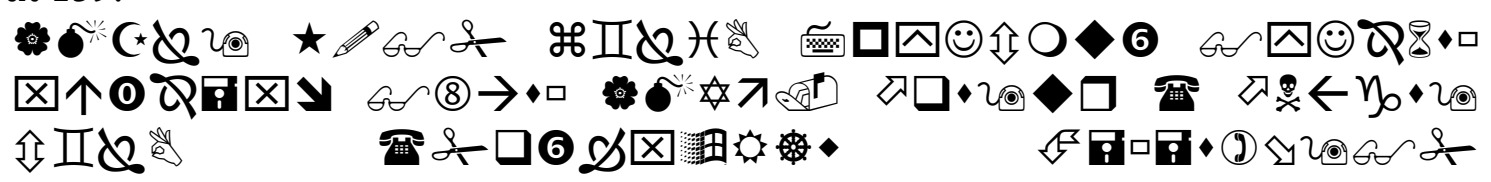

25 Wahbah az-Zuhaili, At-Tafsîr al-Munîr, Jilid. 1, 77.

${ }^{26}$ Ibn Jarîr Ath-Thabari, Jâmi' al-Bayân 'an Ta'wil Ai Al-Qur'ân, Jilid 1 (Beirut: Dâr al-Fikr, 1995), 370.

27 Wahbah az-Zuhaili, At-Tafsîr al-Munîr, Jilid. 2, 433. 


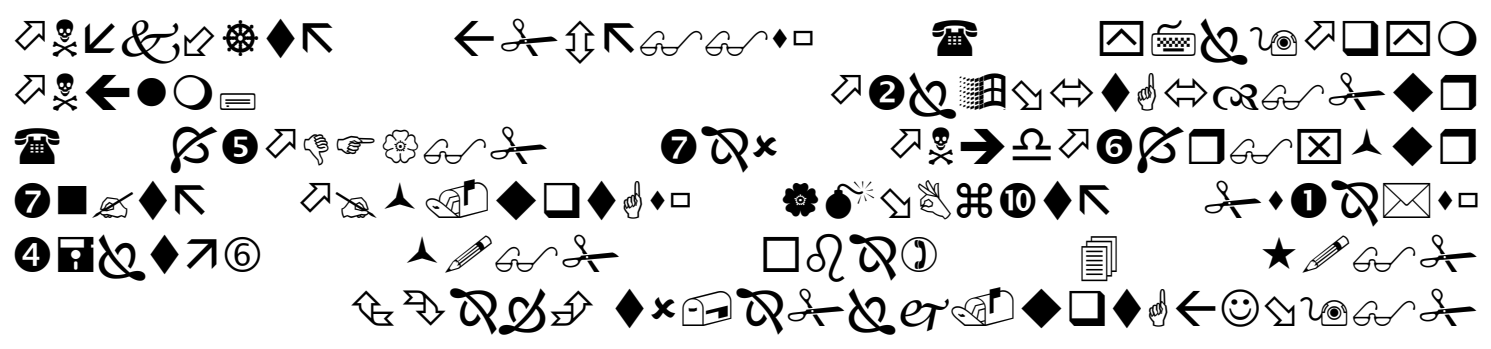

Maka disebabkan rahmat dari Allah-lah kamu berlaku lemah lembut terhadap mereka. Sekiranya kamu bersikap keras lagi berhati kasar, tentulah mereka menjauhkan diri dari sekelilingmu. karena itu ma'afkanlah mereka, mohonkanlah ampun bagi mereka, dan bermusyawarahlah dengan mereka dalam urusan itu, kemudian apabila kamu telah membulatkan tekad, maka bertawakkallah kepada Allah. Sesungguhnya Allah menyukai orang-orang yang bertawakkal kepada-Nya.

M Quraish Shihab, dalam Tafsîr al-Mishbâh, memberikan penjelasan mengenai makna al-mutawakkilîn yaitu diterjemahkan sebagai orang-orang yang bertawakal yaitu penyerahan diri kepada Allah swt yang sebelumnya telah didahului oleh aneka upaya manusia. Kebulatan tekad yang mendahului perintah bertawakal menuntut upaya maksimal manusia, menuntut penggunaan segala sebab atau sarana pencapaian tujuan. Dengan demikian ia adalah kekuatan, sedang tawakal adalah kesadaran akan kelemahan diri dihadapan Allah swt dan habisnya upaya, disertai kesadaran bahwa Allah swt adalah penyebab yang menentukan keberhasilan dan kegagalan manusia. Upaya dan tawakal adalah gabungan sebab dan penyebab." 28

Wahbah Az-Zuhaili dalam At-Tafsîr al-Munîr memberikan pengertian bahwa tawakal adalah: "menggantungkan atau menyandarkan diri kepada Allah swt pada tiap-tiap masalah, sehingga Allah swt mencintai hamba-Nya dan memberikan kecukupan kepada manusia yang bertawakal." ${ }^{29}$ Sementara dalam Tafsîr asy-Sya'râwî̀ didapat keterangan bahwa tawakal adalah : "Menyerahkan dirimu agar mampu mengendalikan dirimu kepada Dzat Yang Maha Benar dengan meyakini bahwa Allah swt akan memberikan yang terbaik dalam pengaturan kehidupan, di mana semua permasalahan dikembalikan kepada Allah swt semata." 30

4. Al-muhsinîn (orang-orang yang selalu berbuat kebajikan) surah Al-Baqarah/2 ayat 195; surah Ăli ‘Imrân/3 ayat 124 dan 148; surah Al-Mâidah/5 ayat 13 dan 93.

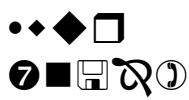
$\star$ or of

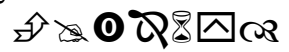
8 Q $x$

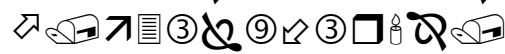

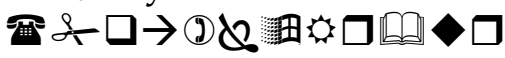
$\square \Omega$ र(ग
O

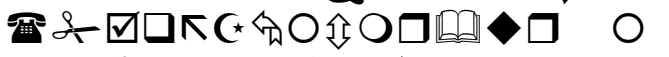

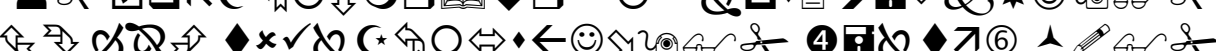
诲 \& $\square \rightarrow$ (d)

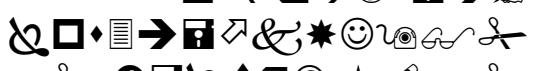

${ }^{28}$ M Quraish Shihab, Tafsîr al-Mishbâh, Vol. 2, 249

${ }^{29}$ Wahbah az-Zuhaili, At-Tafsîr al-Munîr, Jilid. 2, 468.

${ }^{30}$ Muhammad Mutawali Asy-Sya' râwî, Tafsîr asy-Sya'râwî, Jilid. 3, 1842. 
Dan belanjakanlah (harta bendamu) di jalan Allah, dan janganlah kamu menjatuhkan dirimu sendiri ke dalam kebinasaan, dan berbuat baiklah, karena sesungguhnya Allah menyukai orang-orang yang berbuat baik.

Pada ayat di atas memberikan penjelasan bahwa Allah swt mencintai orang-orang yang berbuat baik, di mana yang dimaksud dengan orang-orang yang berbuat baik itu adalah orang-orang yang melakukan segala aktivitas positif, dengan merasaka selalu diawasi oleh Allah swt. Kesadaran akan pengawasan melekat itu, menjadikan seseorang selalu ingin berbuat sebaik mungkin, dan memperlakukan pihak lain lebih baik lagi. ${ }^{31}$ Juga mengandung makna lain, yaitu: “Orang yang mersakan kehadiran Allah swt dalam setiap aktivitasnya dan melakukan intropeksi diri dalam upaya untuk tidak melakukan kesalahan." 32

5. Al-muqsithîn (orang-orang yang selalu berbuat adil) surah Al-Mâidah/5 ayat 42; surah Al-Hujurât/49 ayat 9; surah Al-Mumtahanah/60 ayat 8 .

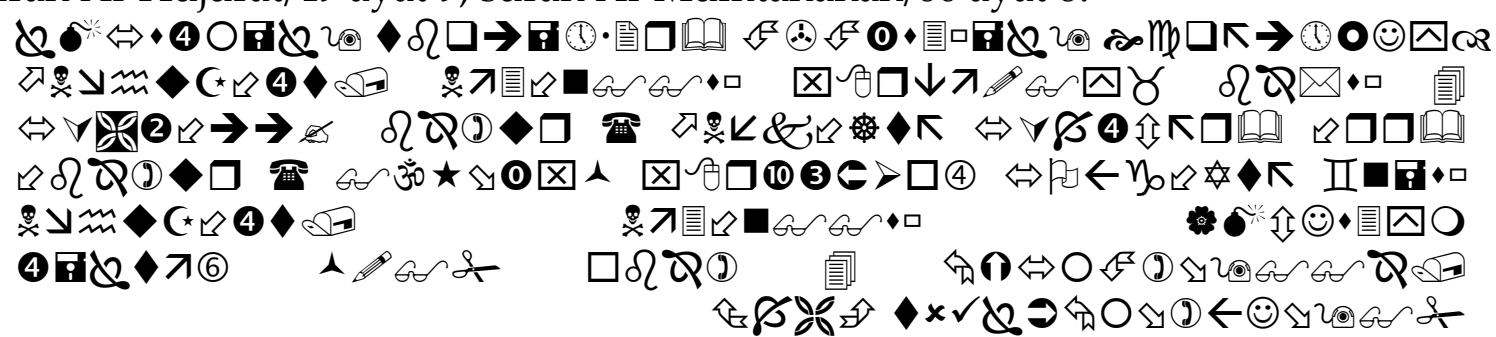

Mereka itu adalah orang-orang yang suka mendengar berita bohong, banyak memakan yang haram. Jika mereka (orang Yahudi) datang kepadamu (untuk meminta putusan), maka putuskanlah (perkara itu) di antara mereka, atau berpalinglah dari mereka; jika kamu berpaling dari mereka, maka mereka tidak akan memberi mudarat kepadamu sedikitpun. Dan jika kamu memutuskan perkara mereka, maka putuskanlah (perkara itu) di antara mereka dengan adil, sesungguhnya Allah menyukai orang-orang yang adil.

Memutuskan perselisihan, atau bertindak adil yang memuaskan semua pihak, adalah sesuatu yang amat sempurna lagi amat terpuji, karena itu pula Rasulullah saw diperintahkan agar jika orang Yahudi datang kepada beliau meminta diputuskan perselisihan mereka, maka beliau dapat menerima atau menolak permintaan itu, tetapi beliau memilih untuk menerima. ${ }^{33} \mathrm{Hal}$ ini menunjukkan bahwa Rasulullah saw memberikan contoh sebagai orang yang berlaku adil, di mana orang yang berlaku adil sangat dicintai Allah Swt.

Al-muqsithîn pada ayat ini diterjemahkan dengan orang-orang yang adil. Hal ini dapat dipahami bahwa adil merupakan sebuah karakter yang harus selalu lekat pada pribadi manusia, khususnya umat Islam, karena di samping dicintai

31 M Quraish Shihab, Tafsîr al-Mishbâh, Jilid. 1, 399.

32 Slamet Firdaus, Konsep Manusia Ideal dalam Al-Qur'ân, Cet. 1 (Ciputat: Makmur Abadi, 2011), 79 .

${ }_{33}$ M Qurasih Shihab, dkk., Ensiklopedia Al-Qur'ân Kajian Kosa Kata, Cet. 1, (Jakarta: Lentera Hati, 2007), 649. 
oleh Allah swt, juga akan memberikan manfaat yang besar pada kehidupan manusia, baik dalam ruang lingkup keluarga, masyarakat dan berbangsa dan bernegara. Sebuah negara akan terwujud kemakmuran dan kesejahteraan, apabila keadilan dapat ditegakkan. Dan sebaliknya, ketika tidak ada keadilan, maka sebuah negara akan mengalami ketidakpastian hidup.

6. At-tawâb̂in (orang-orang yang selalu bertaubat) surah Al-Baqarah/2 ayat 222 .

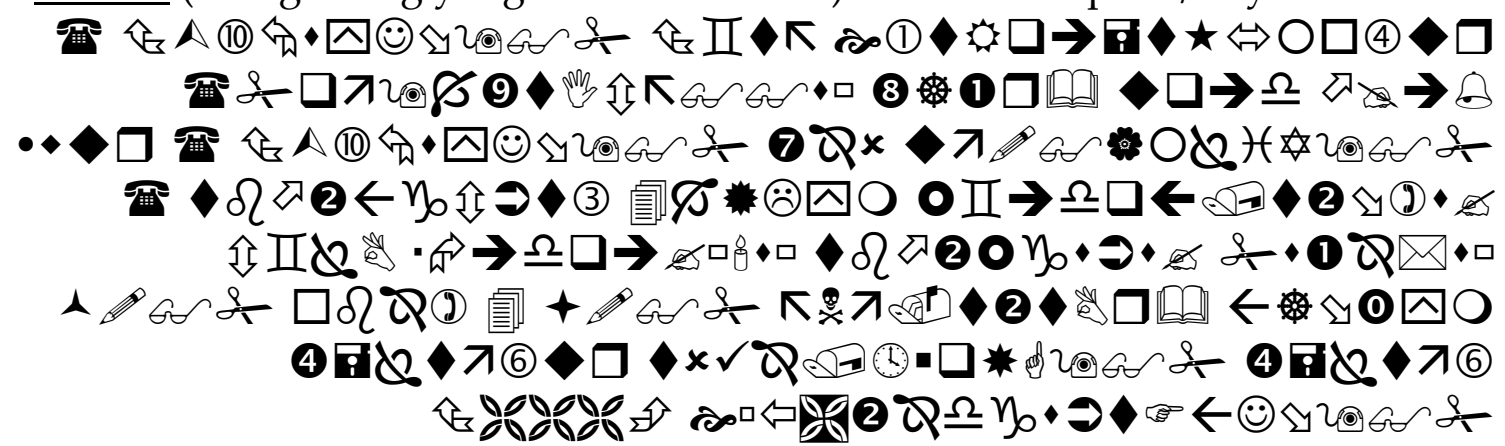

Mereka bertanya kepadamu tentang haidh. Katakanlah: "Haidh itu adalah suatu kotoran". oleh sebab itu hendaklah kamu menjauhkan diri dari wanita di waktu haidh; dan janganlah kamu mendekati mereka, sebelum mereka suci. apabila mereka telah suci, maka campurilah mereka itu di tempat yang diperintahkan Allah kepadamu. Sesungguhnya Allah menyukai orang-orang yang bertaubat dan menyukai orang-orang yang mensucikan diri.

At-tawâbîn diterjemahkan sebagai orang-orang yang taubat. Taubat sangat erat kaitannya dengan penyucian diri dari segala kotoran batin dan merupakan karakter manusia yang tercermin sebagai orang-orang yang dekat dengan Allah swt. Ada beberapa informasi dari ayat Al-Qur'ân yang memberikan jaminan kehidupan bagi orang-orang yang bertobat antara lain: orang-orang yang bertobat akan mendapatkan kebahagiaan hidup (Q.S. An-Nûr/24: 31), mendapatkan ampunan Allah swt dengan dihapus segala dosa dan kesalahannya, juga akan dimasukkan ke dalam surga dan tidak akan dihinakan pada hari Kiamat nanti (Q.S. At-Tahrîm/66: 8). Hal ini pun dicontohkan langsung oleh Rasulullah saw, di mana Rasulullah saw setiap hari selalu bertaubat dan memohon ampunan kepada Allah Swt. Dalam riwayat Imam Al-Bukhari, Rasulullah saw beristigfar dan bertobat kepada Allah swt lebih dari tujuh puluh kali, dan pada riwayat Imam Muslim, Nabi Muhammad Saw bertobat dan beristigfar kepada Allah swt seratus kali setiap harinya.

7. Al-mutathahirîn (orang-orang yang selalu membersihkan dirinya) surah al-Baqarah (2) ayat 222.

Al-mutathahirîn diterjemahkan sebagai orang-orang yang bersungguh-sungguh menyucikan diri. Al-mutathahirîn berkaitan erat kotoran lahir, di mana karakter ini menekankan pada prilaku manusia beriman ketika mau menjalani hubungan badan harus dalam keadaan bersih, terutama bagi wanita yang haid sesudahnya wajib mandi besar, baru diperbolehkan untuk melakukan 
hubungan badan (sex). Dalam konteks ini Islam mengajarkan kepada umatnya agar mempunyai karakter al-mutathahirîn ketika mau melakukan hubungan badan, karena pada dasarnya cikal bakal manusia secara umum melalui hubungan badan. Maka ketika hubungan badan tersebut dilakukan sesuai dengan tuntunan Allah swt dan Rasul-Nya, akan menghasilkan keturunan yang baik, yaitu terciptanya anak-anak yang saleh dan salehah.

8. Al-muthahirîn surah At-Taubah/9 ayat 108.

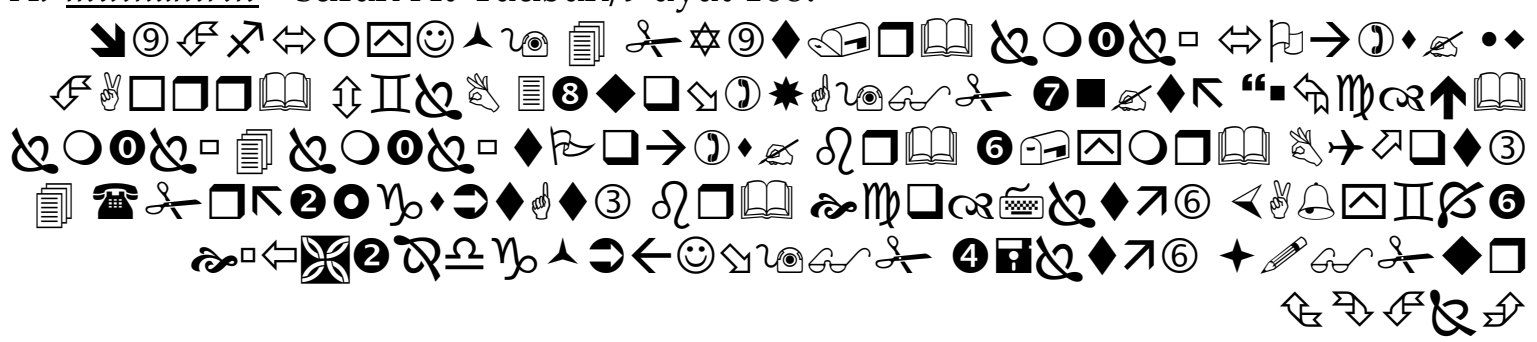

Janganlah kamu bersembahyang dalam mesjid itu selama-lamanya. Sesungguhnya mesjid yang didirikan atas dasar taqwa (mesjid Quba), sejak hari pertama adalah lebih patut kamu shalat di dalamnya. Di dalamnya mesjid itu ada orang-orang yang ingin membersihkan diri. Dan sesungguhnya Allah menyukai orang-orang yang bersih.

M Quraish Shihab, dalam Tafsir al-Mishbah, memberikan penjelasan bahwa: "Al-Muthahhirîn diterjemahkan sebagai orang-orang yang menyucikan diri, yaitu berkaitan dengan mendirikan masjid yang dibangun atas dasar takwa - ketulusan dan ketaatan kepada Allah swt sejak hari pertama hingga selesai bangunannya terus menerus diliputi oleh ketakwaan. Di dalamnya ada orang-orang yang senang menyucikan diri jasmani dan rohani. Dan Allah swt menyukai dengan melimpahkan karunia-Nya kepada orang-orang yang bersungguh-sungguh menyucikan diri, baik yang berada di masjid itu maupun di tempat lain. ${ }^{34}$ Dari penjelasan ini dapat diketahui bahwa ada sebuah karakter yang tidak bisa dipisahkan antara karakter takwa dengan penyucian diri, sehingga wajar Allah swt selalu mencintai orang-orang yang berupaya untuk menyucikan dirinya dari segala dosa dan pelanggaran.

9. Al-ladzîna yuqâtilûn fí sabil Allah (orang-orang yang selalu berjuang di jalan Allah) surah Ash-Shaf/61 ayat 4.

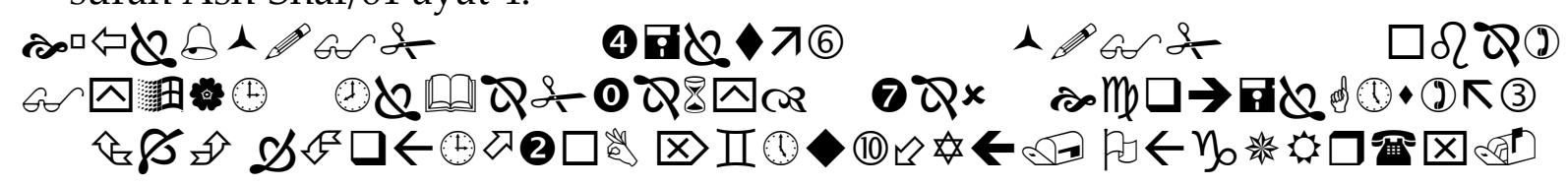

Sesungguhnya Allah menyukai orang yang berperang dijalan-Nya dalam barisan yang teratur seakan-akan mereka seperti suatu bangunan yang tersusun kokoh.

Al-ladzîna yuqâtilûn fî sabil Allah pada surah Ash-Shaf/61 ayat 4 tersebut menggambarkan sebuah karakter orang yang beriman untuk selalu berjuang atau

34 M Quraish Shihab, Tafsîr al-Mishbâh, Vol. 5, 718. 
berjihad di jalan Allah swt selama hayat masih dikandung badan. Di mana ayat sebelumnya mengandung sanksi dari Allah swt serta kecaman terhadap orang yang beriman yang mengucapkan apa yang mereka tidak mengerjakan. Ini menggambarkan sisi pokok dari kepribadian seorang muslim, yaitu kebenaran dan istiqamah/konsisten serta kelurusan sikap, dan bahwa batinnya sama dengan lahirnya, pengamalannnya sesuai dengan ucapannya. ${ }^{35}$

Selain sembilan karakter positif di atas, tentunya masih banyak kepribadian/karakter lainnya yang diabadikan dalam Al-Qur'ân, di antaranya adalah: ${ }^{36}$ al-ihsan, al-istiqamah, al-ishlah baina an-Nas, al-i'tidâl fí al-umur, at-ta'awun, at-tawadhu', al-hikmah, daf'u as-sayyiah bi al-hasanah, ar-rahmah, as-sakinah, salâmah al-qalbi, as-sulûk al-hasan, syukr an-ni'mah, ash-shabru, ash-shidq, al-'affah, kâdhîm al-ghaizh, al-mawaddah, an-nazhafah, dan ikhlas.

\section{Karakter Manusia yang Buruk}

Adapun kepribadian/karakter (akhlak) manusia yang buruk dalam Al-Qur'ân, terdapat 12 kepribadian/karakter yang secara khusus dibenci atau tidak disukai Allah swt sebagai berikut : ${ }^{37}$

1. Al-kâfirîn (mengingkari kebenaran), tertuang dalam surah Ăli 'Imrân/3 ayat 32 dan surah Ar-Rûm/30 ayat 45 sebagai berikut:

Surah Ăli ‘Imrân/3 ayat 32,

\section{苗 क人

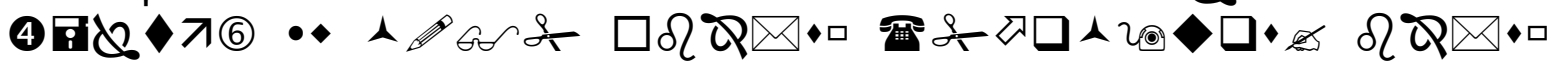

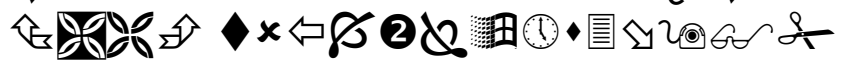

Katakanlah: "Ta'atilah Allah dan Rasul-Nya; jika kamu berpaling, maka sesungguhnya Allah tidak menyukai orang-orang kafir.

Kata al-kâfirîn berasal dari kata kafara, di mana al-kufr lawan dari beriman, yaitu beriman kepada Allah swt, juga termasuk mengingkari/mengkufuri ni'mat yang berlawanan dengan syukur. ${ }^{38}$ Dengan kata lain kafir adalah berpaling dari mentaati Allah swt dan Rasul-Nya, yang mengantarkan Allah swt tidak mencintai orang-orang kafir karena kekufuran mereka. Orang-orang kafir juga mempunyai arti orang-orang yang menutupi tanda-tanda kebesaran Allah swt dan kebenaran yang terhampar dengan jelas di alam raya ini. ${ }^{39}$ Ada juga yang memberikan pengertian bahwa sesungguhnya orang-orang kafir adalah mereka yang

${ }^{35}$ M Quraish Shihab, Tafsîr al-Mishbâh, Vol. 14, 192.

36 Al-Qur'ân Al-Karîm bi ar-Rasm al-`Utsmâni, Al-Insân al-'Alaqât al-Akhlaqiyah, Cet. 4 (Damsyiq: Dâr al-Ma'rufah, 1420 H), 32.

37 Al-Qur'ân Al-Karîm bi ar-Rasm al-'Utsmâni, Al-Insân al-'Alaqât al-Akhlaqiyah, 33.

38 Ibn Mandhur, Lisan al-'Arabiy, Jilid. 7 (Mesir: Dâr al-Hadits, 2003), 688.

${ }^{39}$ M Quraish Shihab, Tafsîr al-Mishbâh, Vol. 1, 93. 
mengingkari ayat-ayat Allah swt dan mendustakan Al-Qur'ân serta mendustakan Nabi Muhammad saw, baik diberi peringatan maupun tidak. ${ }^{40}$

Dari beberapa penjelasan di atas, bisa dipahami mengapa orang-orang kafir itu tidak dicintai oleh Allah swt? Penyebab utamanya adalah mengingkari kebenaran adanya Allah swt, mendustakan Al-Qur'ân dan mendustakan Nabi Muhammad saw sebagai pembawa wahyu Al-Qur'ân, yang sekaligus merupakan utusan Allah swt yang terakhir untuk seluruh umat manusia.

2. Azh-zhâlimîn (orang-orang yang berbuat aniaya) tertuang dalam surah Ăli 'Imrân/3 ayat 57 dan 140, surah Asy-Syurâ'/42 ayat 40 sebagai berikut:

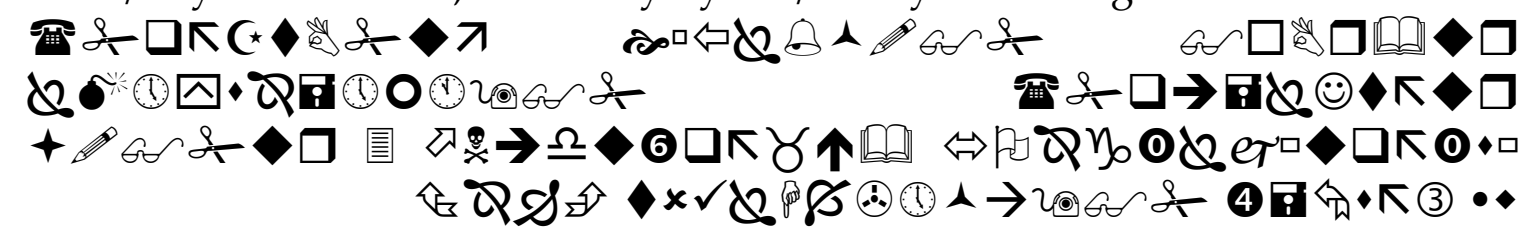

Adapun orang-orang yang beriman dan mengerjakan amalan-amalan yang saleh, maka Allah akan memberikan kepada mereka dengan sempurna pahala amalan-amalan mereka; dan Allah tidak menyukai orang-orang yang zalim.

Ayat di atas, Allah swt secara tegas tidak menyukai orang-orang yang berbuat zalim, karena pada dasarnya orang-orang yang berbuat zalim itu tidak mampu meletakkan sesuatu pada tempatnya, di mana asal dari zalim itu merupakan kesewenang-wenangan atau ketidak adilan yang melampaui batas. ${ }^{41}$ Apalagi dikaitkan dalam pengertian bahwa perbuatan zalim yang dikaitkan dengan syirik yang merupakan perbuatan zalim yang sangat besar (Q.S. Lukman/31 ayat 13). Sehingga wajar saja, orang-orang yang melakukan perbuatan zalim, tidak disukai oleh Allah swt. Padahal Allah s.w.t. adalah Dzat yang Maha menghidupkan dan Maha mematikan, yang Maha pemberi rizki, pemberi nikmat yang Maha Esa tidak ada sekutu bagi-Nya, maka apabila seseorang menyekutukan dengan selain-Nya merupakan kezaliman yang sangat besar. ${ }^{42}$

3. Al-mu'tadîn (orang-orang yang melampaui batas) tertuang dalam surah Al-Baqarah/2 ayat 190, berikut:

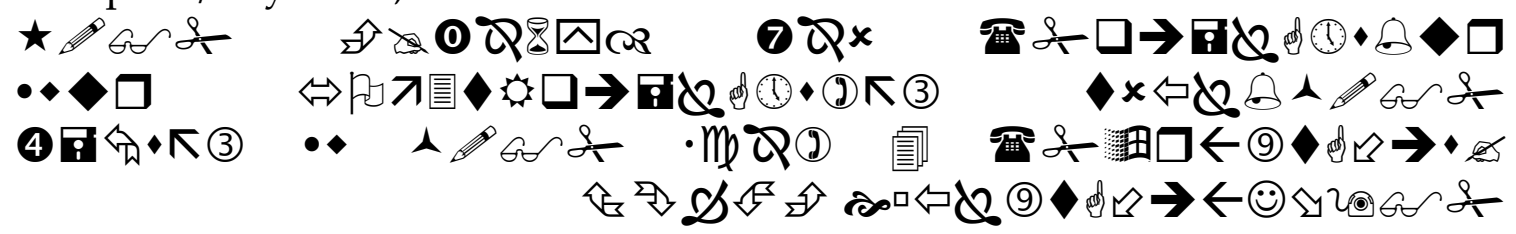

Dan perangilah di jalan Allah orang-orang yang memerangi kamu, (tetapi) janganlah kamu melampaui batas, karena sesungguhnya Allah tidak menyukai orang-orang yang melampaui batas.

\footnotetext{
40 Wahbah Az-Zuhaili, At-Tafsîr al-Munîr, Jilid. 5, 82.

${ }^{41}$ Ibn Mandhur, Lisan al-'Arabiy, Jilid. 6, 38.

42 Ibn Mandhur, Lisan al-'Arabiy, Jilid. 6, 38.
} 
Ayat di atas, mengandung informasi penting yang berkaitan dengan perbuatan melampaui batas, yaitu surah Al-Baqarah/2 ayat 190 berkaitan dengan peperangan, di mana ketika berperang harus berdasarkan perintah Allah swt dalam hal membunuh, bukan berdasarkan hawa nafsu. Juga sasarannya musuh, tidak boleh membunuh wanita, anak-anak, dan orang tua renta, serta tidak boleh membunuh yang bertemu memberikan salam. Bilamana membunuh mereka, maka termasuk orang yang melampaui batas, yang tentunya sangat dibenci Allah swt. ${ }^{43}$

Kemudian akhir teks ayat dari ayat di atas, memberikan penegasan bahwa Allah swt tidak menyukai orang-orang yang berbuat melampaui batas, yaitu ketika terjadi peperangan membunuh musuh dengan penuh hawa nafsu, apalagi membunuh orang-orang yang tidak mempunyai dosa. Berkaitan dengan hal yang dihalalkan Allah swt, tidak boleh mengharamkannya, karena pada dasarnya semua yang dihalalkan Allah swt sudah pasti mengandung hikmah yang besar bagi kehidupan manusia. Juga sebaliknya apa yang telah diharamkan Allah swt, pasti mengandung resiko yang besar ketika manusia melanggarnya. Demikian pula dalam hal memohon kepada Allah swt, diberikan aturan yang jelas dan tegas dengan berendah diri dan suara yang lembut, tidak boleh dengan suara yang keras, juga tidak boleh memaksakan diri dengan berdzikir yang sangat lama, sehingga mengabaikan kewajiban yang lainnya.

4. Al-fasâd (berbuat kerusakan) tertuang dalam surah Al-Baqarah/2 ayat 205 sebagai berikut:

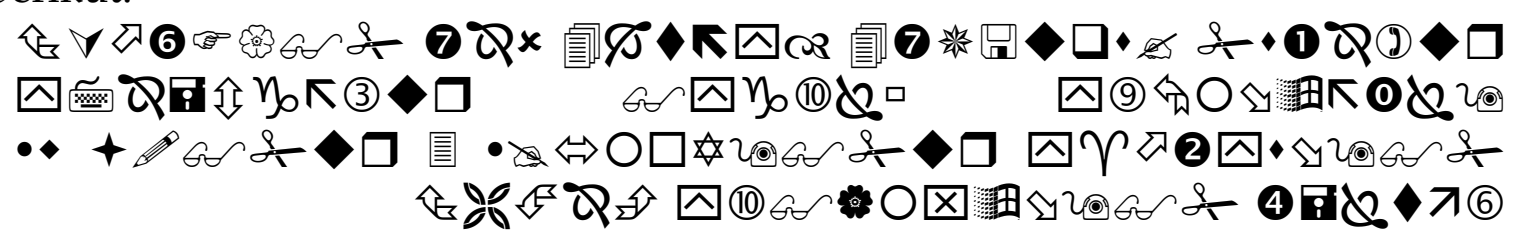

Dan apabila ia berpaling (dari kamu), ia berjalan di bumi untuk mengadakan kerusakan padanya, dan merusak tanam-tanaman dan binatang ternak, dan Allah tidak menyukai kebinasaan.

Kata al-fasâd pada hakikatnya adalah mengeluarkan sesuatu dari tempat yang terpuji dengan dasar bukan untuk tujuan kebaikan atau kebenaran, melainkan kerusakan, yang mengantarkan tidak mendapat ridha Allah swt, melainkan mendapatkan kemurkaan-Nya. ${ }^{44}$ Sehingga dapat dipahami bahwa Allah Swt tidak menghendaki adanya kerusakan di muka bumi ini, melainkan adanya perbaikan-perbaikan dari satu generasi ke-generasi selanjutnya. Walaupun pada kenyataannya saat ini, banyak terjadi kerusakan di muka bumi

${ }^{43}$ Abi Al-Fadhil Syihâb ad-Dîn al-Alusi, Rûh al-Ma'anî fî̀ Tafsîr Al-Qur'ân Al-'Azhîm wa As-Sab' al-Matsanî, Jilid. 1 (Mesir: Dâr al-Hadits, 2005), 648.

${ }^{44}$ Abi Al-Fadhil Syihâb ad-Dîn al-Alusi, Rûh al-Ma'anî fì Tafsîr Al-Qur'ân Al-'Azhîm wa As-Sab' al-Matsanî, 676. 
ini, baik kerusakan yang menyangkut fisik alam/bumi, terlebih kerusakan karakter manusia. Karena pada hakikatnya kerusakan alam/bumi disebabkan ulah manusia yang berkarakter buruk, yaitu selalu membuat kerusakan di muka bumi, tanpa memikirkan jangka panjangnya yang akan dialami oleh generasi berikutnya.

Kepribadian buruk lainnya adalah Al-mufsidîn (orang-orang yang membuat kerusakan) di mana kata al-mufsidîn yang diartikan sebagai orang-orang yang membuat kerusakan, pada dua ayat di atas memberikan informasi bahwa surah Al-Mâidah/5 ayat 64 menjelaskan kerusakan yang diperbuat oleh orang-orang Yahudi, melalui ucapan buruk mereka, yang lahir akibat dengki dan kebencian mereka terhadap Nabi Muhammad saw, yang mendapat wahyu Al-Qur'ân. Di mana ayat tersebut menggambarkan bahwa permusuhan dan kebencian terhadap kaum muslimin akan terus menerus mereka nyalakan sampai hari Kiamat. ${ }^{45}$ Juga yang lebih parah daripada perbuatan Yahudi adalah mereka selalu bersungguh-sungguh membuat tipu daya terhadap orang Islam dan keluarganya, serta menyebarkan fitnah di antara mereka, menyalakan peperangan, mengubah sifat Nabi Muhammad saw, dan mengadakan adu domba. ${ }^{46}$ Dalam sejarah tercatat sampai saat ini, orang-orang Yahudi selalu membuat kerusakan di muka bumi. Sebagai contoh kejadian yang terlewati beberapa waktu, Ghaza diserang Israel (Yahudi) yang membuat kerusakan negeri Palestina, bukan hanya bumi yang rusak di bom bandir, melainkan banyak korban nyawa manusia yang melayang, bahkan sampai ribuan manusia meninggal. Sehingga mengantarkan terhadap yang dilakukan mereka (Yahudi) akan berakibat tidak dicintai Allah swt, mereka jauh dari rahmat Allah swt dan selalu mendapat murka-Nya.

Al-musrifin (orang-orang yang berlebihan), Al-khainin (orang-orang yang berkhianat), Al-mustakbirin (orang-orang yang sombomg) yang menurut $\mathrm{M}$ Quraish Shihab dalam karya monumentalnya "Tafsir al-Mishbah", beliau memberikan keterangan sebagai berikut: "Boleh jadi ada di antara kaum musyrikin itu yang menolak dinamai sombong, dan berkata bahwa mereka menolak apa yang disampaikan oleh Nabi saw, semata-mata karena apa yang disampaikan itu keliru. Nah, untuk itu ayat ini menegaskan bahwa tidak diragukan lagi bahwa sesungguhnya Allah swt yang pengetahuan-Nya mencakup segala sesuatu mengetahui apa yang mereka rahasiakan, yaitu mereka berbohong dalam ucapan mereka itu dan mereka menolak kebenaran tidak lain kecuali karena keras kepala dan Allah swt mengetahui juga apa yang mereka lahirkan. Karena itu, Allah swt menilai mereka sombong dan keras kepala. Sesungguhnya Allah tidak menyukai - tidak melimpahkan anugerah dan ganjaran yang bersifat khusus bagi orang-orang yang sombong, yaitu yang jiwa mereka telah dipenuhi oleh keangkuhan dan telah terbukti keangkuhan itu dalam tingkah laku

${ }^{45}$ M Quraish Shihab, Tafsîr al-Mishbâh, Vol. 3, 145.

46 Abi Al-Fadhil Syihâb ad-Dîn al-Alusi, Rûh al-Ma'anî fî Tafsîr Al-Qur'ân Al-'Azhîm wa As-Sab' al-Matsanî, 492. 
mereka." 47 Dari penjelasan M Quraish Shihab ini, sangatlah jelas bahwa mengapa karakter sombong itu tidak disukai Allah swt, sehingga Allah swt enggan memberikan anugerah dan pahala bagi mereka? Karena prinsip dasarnya karakter sombong di mana pun dan kapan pun mereka adalah orang-orang yang angkuh tidak mau mengikuti apa saja yang disampaikan oleh Nabi Muhamamad saw, terutama dalam melaksanakan shalat, sebagai tiang utama ajaran Islam. Ketika seseorang enggan melakukan shalat, maka sudah dipastikan orang tersebut adalah orang yang memiliki karakter sombong, karena tidak mau mengikuti perintah Allah dan Rasul-Nya.

Adapun dalam referensi lain, didapat informasi uraian sebagai berikut: "Dia (Allah) memberitahukan bahwa hati orang-orang kafir itu mengingkari kehidupan akhirat, sebagimana diberitahukan Allah swt bahwa mereka merasa bangga berbuat demikian. Dan apabila nama Allah saja yang disebutkan, kesallah hati orang-orang yang tidak berimana kepada kehidupan akhirat. Dan apabila nama sembahan-sembahan mereka selain Allah yang disebut, maka mereka bergembira ria. Sedang mereka merupakan orang-orang yang sombong, karena enggan menyembah Allah swt, di samping hatinya mengingkari keesaan-Nya. Sehingga Allah swt akan memasukkan orang-orang yang sombong ke dalam neraka Jahannam sedang mereka kekal di dalamnya." 48 Dari keterangan ini semakin jelas, bahwa kenapa karakter sombong itu sangat dibenci Allah swt? Karena mereka mengingkari Allah swt, yang telah menciptakan mereka, kemudian mereka berpaling dengan menyembah selain Allah. Hal ini terjadi tentunya, karena mereka tidak menggunakan akal fikiran dan hatinya secara jernih, akan tetapi mereka mengikuti doktrin-doktrin negatif yang dibungkus dengan keindahan duniawi.

Al-farihîn (membanggakan diri ) bukannya larangan untuk bergembira, tetapi larangan untuk melampaui batas ketika bergembira, yaitu yang mengantar kepada keangkuhan dan yang menjadikan seseorang tenggelam dalam bidang material, melupakan fungsi harta serta mengabaikan akhirat dan nilai-nilai spiritual. Dari sini diartikan dengan kebanggaan yang luar biasa. Berbangga dengan sesuatu yang haq dapat dibenarkan, selama ia tidak melampaui batas dan selama ia disertai dengan perasaan rendah hati dan bersyukur kepada Allah swt. Nabi Muhammad saw tidak jarang menyebut nikmat-nikmat Allah swt yang melimpah buat beliau, tetapi biasanya beliau mengakhiri sabdanya dengan kata "Wa lâ fakhr" yang diartikan oleh sementara ulama dalam arti "Aku menyebutnya tanpa berbangga-bangga" atau berarti "Tidak ada kebanggaan melebihi hal ini". ${ }^{49}$ Sehingga dapat dipahami bahwa bergembira itu pada hakikatnya diperbolehkan, selama tidak melampaui batas. Akan tetapi

47 M Quraish Shihab, Tafsîr al-Mishbâh, Vol. 7, 209.

48 Muhammad Nasib ar-Rifa'i, Kemudahan dari Allah: Ringkasan Tafsir Ibnu Katsir, Terj. Syihabuddin, Cet. 3, Jilid. 2 (Jakarta: Gema Insani Press, 2001), 1020.

${ }^{49}$ M Quraish Shihab, Tafsîr al-Mishbâh, Vol. 10, 404-405. 
kegembiraan itu yang bersifat melampaui batas dan berakibat membanggakan dirinya karena berbagai macam sebab, apakah karena harta yang banyak, jabatan, keturunan atau kecantikan? Maka bisa akan mengantarkan kepada hal yang dibenci Allah swt, sebagaimana dijelaskan ayat di atas, bahwa Karun terlalu bangga dan membanggakan dirinya karena mempunyai harta yang sangat banyak, bahkan mengatakan harta yang dia miliki adalah hasil dari ilmunya, bukan merupakan anugerah dari Allah Swt.

Kaffarin atsîm (kekafiran dan berbuat dosa) merupakan kepribadian/karakter kekafiran dan perbuatan dosa besar, di mana kata "Kaffar atsîm" keduanya merupakan shighat mubalaghah yang berarti "'Azhim al-kufr syadid al-itsm- sangat kafir serta selalu melakukan dosa yang besar, ${ }^{50}$. Mukhtal fakhûra (sombong dan membanggakan diri), As-s $\hat{u}^{\prime}$ min al-qaul (perkataan buruk). Itulah di antara kepribadian/karakter buruk manusia yang diabadikan dalam Al-Qur'ân yang secara khusus, yaitu kepribadian/karakter yang dibenci atau tidak disukai Allah Swt.

Dari beberapa uraian di atas dengan mengetengahkan kepribadian yang baik dan buruk manusia yang dibadikan Al-Qur'an, akan menjadi pelajaran yang sangat berharga dalam membangun pendidikan keluarga di atas pundi-pundi Rabbaniyyah. Dengan kata lain, tanamkan nilai-nilai kepribadian yang baik tersebut dalam kehidupan sejak dini kepada generasi ke generasi berikutnya dalam pendidikan keluarga. Di mana manusia yang menginginkan kehidupan yang penuh kebahagiaan di dunia dan akhirat, maka ia akan memilih kepribadian/karakter yang mengantarkan kepada kebaikan dan mencontoh pelaku-pelakunya, yaitu para Nabi dan Rasul Allah, serta orang-orang yang mengikuti jejak langkah mereka, baik dari kalangan para sahabat, tabi'în, tabi' at-tabi'în sampai pada masa sekarang. Dan sebaliknya barangsiapa yang mengikuti hawa nafsunya, yang akan mengantarkan kepada kesulitan dan kesengsaraan hidup di dunia dan akhirat, maka kepribadian/karakter yang dicontoh adalah musuh-musuh Allah swt dan para utusan-Nya. Contoh yang paling popular adalah Fir'aun - ia mengaku sebagai tuhan, karena sederetan kepribadian/karakter buruk melekat padanya, yaitu kafir, musyrik, takabur, riya dan lainnya. Demikian pula pada zaman Rasulullah saw, sederetan orang yang mempunyai karakter buruk Nampak jelas sangat memusuhi Rasulullah s.a.w. dan para sahabat beliau, di antaranya : Abu Jahal, Abu Lahab, dan lain-lainnya.

\section{KESIMPULAN}

Membangun pendidikan keluarga di atas pundi-pundi Rabbaniyyah merupakan suatu keharusan, bilamana menginginkan terciptanya kehidupan yang penuh dengan kebahagiaan, keharmonisan, ketentraman, kenyamanan, keamanan, kesejahteraan, dan terwujudnya keadilan sosial bagi seluruh bangsa Indonesia. Salah

50 Wahbah Az-Zuhaili, At-Tafsîr al-Munîr, Jilid. 2, 92. 
satu upayanya adalah menerapkan nilai-nilai kepribadian yang dicintai Allah SWT dalam kehidupan nyata, dan berusaha menjauhkan diri dari kepribadian yang tidak disukai Allah SWT.

\section{DAFTAR PUSTAKA}

Al-Qur'ân Al-Karîm

Al-Qur'ân Al-Karîm bi ar-Rasm al-Utsmâîi, Al-Insân al-'Alaqah al-Akhlaqiyah, Damsyiq: Dâr al-Ma'rufâh, cet. 4, 1420 H.

Abd al-Baqi, Muhammad Fuad, Al-Mufahras li Alfaz Al-Qur'ân Al-Karîm, Mesir: Dâr al-Hadits, $1422 \mathrm{H} / 2001 \mathrm{M}$.

Agustian, Ary Ginanjar, ESQ Emotional Spirittual Quotient, Jakarta: Arga, cet. 1, 2001. Ali, Atabik dan Ahmad Zuhdi Muhdlor, Kamus Kontemporer Arab-Indonesia, Yogyakarta: Yayasan Ali Maksum, cet. 1, 1996. 
Al-Ishfahani, Abu al-Qasim Abu al-Husain bin Muhammad al-Ragib, Al-Mufradât fî Garîb Al-Qur'ân, Mesir: Mustafâ al-Bâb al-Halâbî, 1961.

Al-Jamal, Muhammad Abd al-Mun'im, At-Tafsîr al-Farî̀ Lil Qur'âa Al-Majîd, Kairo: Research Publicaation Dept, cet. 1, 1952.

Al-Jazairi, Abu Bakar Jabir, Tafsîr Al-Qur'ân Al-Aisir, penerjemah: M Azhari Hatim dan Abdurrahman Mukti, Jakarta: Darus Sunnah, cet. 2, 2011.

Al-Jurzani, Asy-Syarîf bin Muhammad, Kitâb at-Ta'rifât, Beirut: Dâr al-Kutub al-Islâmiyah, cet. 1, 2012.

Al-Khalidy, Shalah, Kisah-kisah Al-Qur'ân Pelajaran dari Orang-orang Dahulu, penerejemah: Setiawan Budi Utomo, Jakarta: Gema Insani Press, cet. 3, 2000.

Al-Alusi, Shihab al-Din Sayyid Mahmud, Rûh al-Ma'ani fî̀ Tafsîr Al-Qur'ân, Beirut: Dâr Ihya' al-Turas, t.th.

Al-Maghlouth, Sami bin Abdullah, Atlas Tarikh al-Anbiyâ' wa ar_rasul, edisi terjemah: Atlas Sejarah Para Nabi \& Rasul Menggali Nilai-nilai Kehidupan para Utusan Allah, penerjemah: Qasim Shaleh, dkk, Jakarta: Almahera, cet. 4, 2012.

Al-Mun'im, Muhammad Abdul, Al-Jamal at-Tafsîr al-Farîd lî̀ Al-Qur'ân Al-Majîd, Kairo: Research Publication Dept, cet. 1, 1952.

An-Naisâbûrî, Abî Hasan Muslim bin al-Hajâj al-Qusyairî, Shahih Muslim, Mesir: Dâr al-Hadîs, cet. 1, 1997.

Ar-Razi, Fakh al-Din, At-Tafsîr al-Kabîr, ditahqiq oleh Khalîl Muhyiddîn, Beirut: Dâr al-Fikr, 1994.

Ar-Rifai, Muhammad Nashib, Kemudahan dari Allah Ringkasan Tafsîr Ibnu Katsîr, penerjemah: Syihabuddin, jilid. 1,2,3,4, Jakarta: Gema Insani, cet. 3, 2001.

Asy-Sya'râwî, Muhammad Mutawali, Tafsîr asy-Sya'râwî̀, jilid. 1, 2, 12, 17, Kairo: Idarah al-Kutub wa al-Maktabat, 1411 H/1991 M.

Ath-Thabari, Abû Ja'far Muhammad bin Jarîr, Jâmi' al-Bayân fî̀ Tafsîr Ayi Al-Qur'ân, jilid. 1, 4, 7, 8, 9, Beirut: Dâr al-Fikr , 1988.

Az-Zuhaili, Wahbah, At-Tafsir al-Munîr, jilid. 1, 2, 5, Beirut: Dâr al-Fikr, cet. II, 1426 $\mathrm{H} / 2005 \mathrm{M}$ At-Tafsîr al-Wasîth, jilid. 1, 2, 3, Beirut: Dâr al-Fikr al-Mu'hsir, cet. 1, 2001.

Baharuddin, Paradigma Psikologi Islam; Studi tentang Elemen Psikologi dan Al-Qur'ân, Yogyakarta: Pustaka Pelajar, cet. 1, 2004.

Faqih, Kamal dan Tim Ulama, Tafsîr Nûrul Qur'ân, penerjemah: R Hikmat Danaatmaja, Jakarta: Penerbit al-Huda, cet. 1, 2003.

Firdaus, Slamet, Konsep Manusia Ideal Dalam Al-Qur'ân (Studi Profil al-Musin dalam Perspektif Tafsîr Ayat-ayat Ihsan), Tangerang: Makmur Abadi Press, cet. 1, 2011.

Hamka, Tasauf Moderen, Jakarta: Pustaka Panjimas, 2000. Tafsîr al-Azhar, jilid. 1, 3, 5, 6, 9, 11, 12, 17, 23, Jakarta: Panji Masyarakat, TT.

Hanafi, Muchlis Muhammad dkk, Tafsîr Al-Qur'ân Tematik, Al-Qur'ân dan Kenegaraan, Jakarta: Lajnah Pentashihan Mushhaf Al-Qur'ân, cet. 1, 2012. 
Tafsîr Al-Qur'ân Tematik, Kenabian (Nubuwwah) dalam Al-Qur'ân, Jakarta: Lajnah Pentashihan Mushhaf Al-Qur'an, cet. 1, 2012.

Al-Qur'ân dan Kenegaraan, Jakarta: Lajnah Pentashihan Mushhaf Al-Qur'an, cet. $1,2012$.

Hanbali, Ahmad bin Muhammad bin, Al-Musnad, Mesir: Dâr al-Hadîs, cet. 1, 1995.

Hude, M Darwis, Emosi Penjelajahan Religio-Psikologis tentang Emosi Manusia di dalam Al-Qur'ân, Jakarta: Erlangga, cet. 1, 2006.

........, Logika Al-Qur'ân Pemaknaan Ayat Dalam Berbagai Tema, Jakarta: PT Nagakusuma Media Kreatif, cet. 1, 201.

Kesuma, Dharma, dkk, Pendidikan Karakter Kajian Teori dan Praktek di Sekolah, Bandung: PT Remaja Rosdakarya, cet. 1, 2011.

Kodir, Abdul, Konsep Manusia Dalam Al-Qur'ân sebagai Dasar Pengembangan Pendidikan, Jakarta: Disertasi UIN Syarif Hidayatullah, 2007.

Kurniawan, Syamsul, Pendidikan Karakter Konsepsi dan Implemnetasinya secara Terpadu di Lingkungan Keluarga, Sekolah, Perguruan Tinggi, dan Masyarakat, Jakarta: Ar-Ruzz Media, cet. 1, 2013.

Lickona, Thomas, Character Matters, New York, Touchstone Rockefeller Center, 2004. Educating for Character, edisi terjemahan: Mendidik untuk Membentuk Karakter, penerjemah: Juma Abdu Wamaungo, Jakarta: PT Bumi Aksara, cet. 1, 2012.

Majid, Abdul dan Dian Andayani, Pendidikan Karakter Perspektif Islam, Bandung: PT Remaja Rosdakarya, cet. 1, 2011.

Mandhur, Ibn, Lisan al-'Rabiy, jilid. 2, 5, 6, 7, 9, Mesir: Dâr al-Hadits, 2003.

Megawangi, Ratna, Pendidikan Karakter Solusi yang Tepat untuk Membangun Bangsa, Bogor: Indonesia Heritage Foundation, cet. 1, 2004.

Mulyasa, H E, Manajemen Pendidikan Karakter, Jakarta: PT Bumi Aksara, cet. 2, 2012. Naim, Ngainum, Charakter Building Optimalisasi Peran Pendidikan dalam Pengembangan Ilmu \& Pembentukan Karakter Bangsa, Jogjakarta: Ar-Ruzz Media, cet. I, 2012.

Nata, Abuddin, Akhlak Tasawuf dan Karakter Mulia, Jakarta: PT Raja Grafindo Persada, cet. 13, 2014.

Quthb, Sayyid, Fî Zhilal Al-Qur'ân, Beirut: Dâr asy-Syuruq, 2008.

Saihu, Pendidikan Karakter Berbasis Kearifan Lokal (Studi Di Jembrana Bali)", Edukasi Islami: Jurnal Pendidikan Islam, Vol: 08, No: 01 (2019): 69-90.

Sahlan, Asmaun dan Angga Teguh Prastyo, Desain Pembelajaran Berbasis Pendidikan Karakter, Jogjakarta: Ar-Ruzz Media, cet. 1, 2012.

Salahuddin, Anas dan Irwanto Alkrienciehie, Pendidikan Karakter: Pendidikan Berbasis Agama dan Budaya Bangsa, Bandung: Pustaka Setia, cet. 1, 2013.

Samani, Muchlis dan Hariyanto, M.S, Konsep dan Model Pendidikan Karakter, Bandung: PT Remaja Rosdakarya, cet. 1. 2011.

Shihab, Muhammad Quraish, Tafsîr al-Mishbâh, jilid. 1, 2, 3, 4, 5, 6, 7, 8, 10, 11, 12, 13, 14, 15, Jakarta: Lentera Hati, cet. I, 2000.

, Tafsir Al-Qur'ân Al-Karîm Tafsîr atas Surat-surat Pendek Berdasarkan Urutan Turunnya Wahyu, Bandung: Pustaka Hidayah, cet. II, 1997. 
........., Mukjizat Al-Qur'ân Ditinjau dari Aspek Kebahasaan Isyarat Ilmiah dan Pemberitaan Gaib, Bandung: Mizan, cet. 4, 1998.

........, Wawasan Al-Qur'ân, Bandung: PT Mizan Pustaka, cet. xiv, 2003.

Surasman, Otong, Bercermin Pada Nabi Ibrahim As, Jakarta, Gema Insani Press, cet. 1, 2016.

Zakariya, Abû al-Husain Ahmad bin Faris bin, Mu'jam al-Maqâyis fî al-Lughah, Beirut: Dâe al-Fikr, cet. 1, 1994.

Zubaedi, Desain Pendidikan Karakter Konsepsi dan Aplikasinya dalam Lembaga Pendidikan, Jakarta: Kencana, , cet. 1, 2012. 